\title{
Saha Türkleri, Hantı-Mansi, Nenets Topluluklarında Ayı Töreni ve Törende Kullanılan Çalgılar*
}

\section{Feyzan Göher Vural ${ }^{* *}$}

Öz

Tören ve festivaller, bir topluluğun kültürel zenginlikleri içinde önemli bir yere sahiptir. Törenlerde yer alan uygulamalar, toplumun tarihi ve sahip olduğu değerleri hakkında önemli ipuçları barındırır.

Saha (Yakut) Türkleri ile Sibirya’nın yerli halklarından oldukları düşünülen Hantı-Mansiler, Nivhler ve Nenetsler arasında yüzlerce yıllık bir geçmişe sahip olan "ayı töreni”, içerdiği ritüller ve müzikal uygulamalar açısından kendine has, farklı özellikler barındırır. Orta Asya Türk ve yakın komşu/akraba toplulukları arasında, doğa varlıklarını kutsal sayma inanışı ile bağlantılı olan bu tören, kapsamlı ritüeller içerir. Ayının avlanması, öldürülmesi ve etinin yenmesi bazı uygulamalar eşliğinde yapılır. $\mathrm{Bu}$ uygulamalar içinde müzik ve çalgılar özel bir yere sahiptir.

Betimsel karakterli bu çalışma, ağırlıklı olarak Rusça, bunun yanı sıra Türkçe ve İngilizce kaynakların taranması ve alan araştırması sonucu elde edilen bulguların, tarihsel ve müzikolojik saptamalarının yapılması, yorumlanmasına dayanmaktadır. Çalışmada Ayı Töreninin kökeni, ritüelleri, bu törende kullanılan çalgıların yanı sıra, sadece bu tören ile özdeşleşen brevne gibi çalgıların nitelikleri, kullanılış amaçları vurgulanmıştır.

\section{Anahtar Kelimeler}

Ayı Töreni, Saha (Yakut) Türkleri, Hantı Mansi, Nenets, müzikoloji.

\footnotetext{
Geliş Tarihi: 29 Aralık 2016 - Kabul Tarihi: 01 Mart 2017

Bu makaleyi şu şekilde kaynak gösterebilirsiniz:

Göher Vural, Feyzan (2019). "Saha Türkleri, Hantı-Mansi, Nenets Topluluklarında Ayı Töreni ve Törende Kullanılan Çalgılar”. bilig - Türk Dünyası Sosyal Bilimler Dergisi 88: 83-112.

** Prof. Dr., Niğde Ömer Halisdemir Üniversitesi, Türk Musikisi Devlet Konservatuvarı, Müzikoloji Bölümü - Niğde/Türkiye

ORCID ID: https://orcid.org/0000-0001-5313-0763

feyzan_goher@yahoo.com
} 


\section{Giriş}

Türk tarihi ve kültürü açısından Sibirya’nın büyük bir önemi vardır. Bu bölgeye ilişkin bilgilerin XVI. yüzyıla kadar birinci el kaynaklardan takip edilememesi büyük bir problem yaratsa da, mevcut verilerin derlenerek Türk kültürü açısından değerlendirilmesi önemlidir. Nitekim Rusların SSCB döneminde yaptığı arkeolojik kazılar, burada var olan tarihi kültürün, Türk kültürüyle eşdeş olduğunu ortaya koymaktadır (Topsakal 2011: 1863). Bununla birlikte, Hantı-Mansiler, Nivhler ve Nenetsler gibi Sibirya halklarının kökenleri ve tarihlerine ilişkin araştırmalara göz attığımızda, pek çok kez Türklerle olan bağlantıların yok sayıldığını görürüz. Bu durumu gerek Rus, gerekse Batılı kaynaklar için söylemek mümkündür.

Saha (Yakut) Türkleri ile Sibirya’nın yerli halklarından oldukları düşünülen Hantı-Mansiler, Nivhler ve Nenetsler arasında yüzlerce yıllık bir geçmişe sahip olan "Ayı Töreni”, Türk ve Sibirya kültürü açısından önemlidir. Bununla birlikte Türk araştırmacıların bu konuya pek eğilmediğini; konu ile ilgili genellikle Rus araştırmacıların ve az sayıda Batılı akademisyenin çalıştığını söylemek mümkündür. Bu tören, içerdiği ritüller ve müzikal uygulamalar açısından kendine has, farklı özellikler barındırır. Orta Asya Türk ve yakın komşu / akraba toplulukları arasında, doğa varlıklarını kutsal sayma inanışı ile bağlantılı olan bu tören, kapsamlı ritüeller içerir.

Literatür taraması ve alan araştırmasına dayalı ve betimsel karakterli bu çalışma, özellikle kuzey doğu Asya Türk kültürü ve Sibirya kültüründe önemli bir yere sahip olan Ayı Töreni'nin özelliklerini ortaya koymak amacıyla gerçekleştirilmiştir. Kökenleri Tölös ve Kıpçak boylarına dayanan Saha Türkleri (Gömeç 1998: 177), eski gelenek ve göreneklerini korumaları nedeniyle, kültürel tarih bakımından özel bir yere sahiptir. Sibiryả nın yerel halklarından olan Hantı-Mansiler, Nivhler ve Nenetsler ile Saha Türkleri arasında günümüzde de devam eden Ayı Töreni ve söz konusu törende kullanılan çalgılar, bu çalışmanın temel konusunu oluşturmaktadır. Bununla birlikte sözü edilen Sibirya halkları ile Türkler arasındaki benzerliklerin de altı çizilmiştir. Ayı Töreni konusunda araştırmalar yapan Rus biliminsanları içinde, T.N. Dimitrieva, N.L. Gondatti, V. Vorobeva, N.N. Haruzin, V. Nikolayeva, E.V. Liarskaya, A.M. Zolotarev, V. Novitsky, J. Fedotoviç, E.V. Fadeeva, V.N. Çernetsov, Ç.M. Taksami sayılabilirr ${ }^{1}$. B.A. Vasilev’ in de bu külte ilişkin detaylı bir araştırması mevcuttur. Bu çalışmada ayının avlanması, etlerinin ve kemiklerinin ayrılması, yenilmesine yönelik ritüellere ilişkin detaylı bilgiler yer alır. A.V. Smolyak ise bu geleneğin hangi kültürlerde görüldüğüne ilişkin 
bir araştırma yapmıştır. Yakın zamanlarda Natalya Mamçeva tarafından gerçekleştirilen sanatta yeterlik tezinde de konuya ilişkin bilgiler yer almaktadır. Konunun ekseriyetle Rus araştırmacılar tarafından çalışılmış olması nedeniyle, bu makalenin kaynak taraması aşamasında yoğun olarak Rusça kaynaklardan faydalanılmış; kaynaklar bizzat araştırmacı tarafından Türkçeye çevrilmiştir. Rusça ve İngilizce kaynaklarla birlikte, söz konusu törenin eski Türk inanışları ile olan bağlarını ortaya koymak adına, Genel Türk Tarihi kaynakları da kullanılmıştır. Çalışmada ayrıca Yakutistan (Saha) Özerk Cumhuriyetine yapılan araştırma gezisinden elde edilen notlar ve kuzey ve güney Sibirya müzikologları ile yapılan görüşmelerden elde edilen bilgiler de kullanılmıştır. Tasnif kısmında, bilgilerin alt başlıklar halinde sistematik şekilde sınıflandırması yoluna gidilmiştir.

Kaynakların tahlili aşamasında veriler, birden çok kaynaktan teyit edilerek doğrulanmaya gayret edilmiştir. Bu aşamada, "Ayı Töreni, ayı kültü kökenli midir?", “Türk kültüründe ayı kültünün yeri nedir?”, "Ayı kültü hangi toplum ya da topluluklarda görülmektedir?", "Bu topluluklarının Türklerle olan benzerlikleri nelerdir?", "Ayı Töreninde ne gibi uygulamalar gerçekleştirilir?”, "Ayı Töreninde müziğin konumu nedir?”, "Ayı Töreninde kullanılan çalgılar nelerdir?”, "Bu törenle özdeşleşmiş çalgılar ve müzikal uygulamalar var mıdır?” sorularına cevaplar aranmış, tarihi kaynaklar ışığında yorumlamalar yapılmışır. Araşıırmanın enstrümanlarla ilgili olan kısmında ise müzikolojik bir yaklaşım izlenmiştir.

Bu makale, Hantı-Mansi, Nivh ya da Nenetslerin kökenlerini araştırmaya yönelik bir nitelik taşımamaktadır. Aynı şekilde yeterli deliller mevcut olana dek, söz konusu toplulukları Türk ilan etme gibi bir sav da ortaya atılmamaktadır. Ancak, Rus ve Batılı araştırmacıların tersine, Türkler ile Hantı-Mansiler, Nivh ve Nenetsler arasındaki büyük kültürel benzeşimin de altı çizilecektir. Ayı Töreni ve bağlantılı olduğu ayı kültüne geçmeden evvel, Orta Asya Türklerinde Törenler, Saha (Yakut) Türkleri, Hantı-Mansiler, Nivhler ve Nenetslerden kısaca söz etmek yerinde olacaktır.

Orta Asya Türklerinde Törenler: Orta Asya Türklerinin, Eski Türk İnanışı kökenli, doğa devinimleri kaynaklı, av, savaş ya da farklı toplumsal olaylardan doğmuş çeşitli törenleri vardır. Örneğin Çinlilere ait Shıh Chi ve Hou Hanshu kitaplarında Hunların gerçekleştirdiği dini ve din dışı törenlere ilişkin bilgiler edinebilmek mümkündür (Ögel 1982: 73). Bu törenlerde bayram gibi kutlamalar gerçekleşir, at yarışları yapılır, şarkılar söylenir, bol miktarda kımız içilirdi (İzgi 1977: 32, Groot ve Asena 2011: 85). Hunların devamı 
niteliğindeki Kök Türklerin hayatında da çeşitli amaçlarla geçekleştirilen törenler büyük yer tutmuştur. Bunların içinde, Kök Türklerin Kutlu Dağ’da gerçekleştirdikleri gök ayini ile yer ve su ayinleri sayılabilir (Esin 2004: 27). Doğan güneşi üç veya dokuz defa selamladıkları bir tören düzenleyen Uygurlar ise (Ögel 1988: 207, Baykara 2001: 54), baharın gelişini yeni bir yılın başlangıcı sayarlar ve bu nedenle şenlikler yaparlardı (Rasonyi 1993: 35). Orta Asya Türkleri arasında çoban topluluklarında hayvanların yavrulaması veya koyun kırkma zamanlarında özel törenler düzenlenirdi (Gömeç 1998: 192). Müzik, tüm bu törenlerin vazgeçilmez unsurlarından birisi olarak kabul görmüştür. Tahta çıkış törenlerinde, ziyafetlerde, evlenme törenlerinde, kabul törenlerinde, cenaze törenlerinde, av törenlerinde ve yıllık düzenli olarak gerçekleştirilen törenlerde, tuğ takımları, kamlar, ozanlar ya da müzik gruplarınca farklı yapıda müzikler icra edilmiştir. Fiziki çevrede bulunan dağ, deniz, ırmak, ateş, fırtına, gök gürültüsü, ay, güneş, yıldızlar gibi tabiat şekillerine ve hadiselerine karşı hayret ve korkuyla karışık bir saygı hissi, eskiden beri pek çok kültürde var olmuştur (Çavuşoğlu 1986: 30). Bununla birlikte Türkler arasında doğa varlıklarına duyulan sevgi ve saygı, üst düzeydedir. Eski Türkler tabiatta bazı gizli kuvvetlerin varlığına inanmışlar; bunları kutsal (yani ıduk) kabul etmişlerdir. Bu durum, dini inanışlarına ve törenlerine yansımıştır. Ayı töreni de doğa güçlerine saygı temelli bir özelliğe sahiptir.

Saha (Yakut) Türkleri: Orta Asya’nın kuzey bölgesinde yaşayan Sahalar, Yakut adı ile de bilinmektedir. Bugünkü "Yakut" kelimesi Evenk (Mançu - Tunguz) dilinden gelmektedir. Evenkilerin Sahalara Eko dedikleri söylenmektedir ve Sahalara ait ilk bilgileri Evenkilerden alan Ruslar, E sesini Ya sesine çevirip -ut ekini de ekleyerek, Eko adını Yakut’a dönüştürmüşlerdir (Fedotoviç 1994: 227).
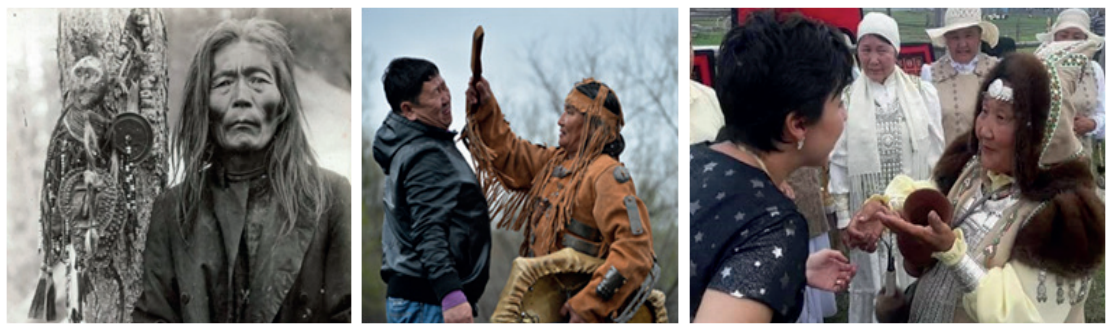

Resim 1. (solda) Evenk Kamı (Şamanı) (Fedor Poligus 1901-1903 - Шаманы, Колдуны и их Духи)

Resim 2 ve 3. Günümüz Saha Kamı ve Tören Esnası (Духи агропарка)

Resim 3. Günümüz Saha Kamı (Kangalas Bölgesi/Yakutistan 2017 - Kişisel Arşiv) 
Saha kamları törenlerinde ateşe süt ve ekmek sunma geleneklerini günümüzde de devam ettirmektedirler. Yukarıda sağda bir Saha kamının tören sonrası bizi kabul ederek alnımıza ateş isi sürmesi görülmektedir.

Arkeolog Dr. Maçanov'un başkanlığında, Lena Nehri'nin sağ kıyısında Diring-Üryah bölgesinde 1982 yılında yapılan kazılarda, Sahaların bugün bulundukları coğrafyada 3 milyon yıl öncesine uzanan arkeolojik bulgular ele geçmiştir. Bu bölgede 10'a yakın arkeolojik buluntu yeri olması, tarihsel ve kültürel derinliği ortaya koymaktadır. Saha Türklerinin şekillenmesinde iki büyük Türk grubu önemli rol oynamıştır. Birinci grubu eski Tölös aşiretleri teşkil eder ki, Tölösler bilindiği üzere teşkilatsız Türk gruplarıdır. İkinci grubu ise, Kıpçak boyları oluşturmaktadır (Gömeç 1998: 177-179). Saha Türklerinin hayatında Eski Türk İnanışı çok önemli bir rol oynamıştır. Bugün de Şamanizm inanışı içinde bu merasimler yapılmaya devam etmektedir. Saha bilim adamlarına göre bugünkü Şamanizm, eski Türk dininin felsefi, sanatsal ve tıbbi yönlerini göstermektedir. Destanlar ve destan anlatıcılarına büyük değer veren Sahaların (İllarionov 2013: 3), geleneksel müziklerinde pentatonik, yani Orta Asya Türk Müziğinin tipik özelliklerinden olan beş perdeli dizi hâkimdir. Bu, bir anlamda oligotonik² bir özelliktir. Nitekim Skrıbıkina (2007: 166), geleneksel Yakut müziğinin oligotonik bir yapı izlediğini belirtir. Kültürel özelliklerini büyük ölçüde yaşatmaya devam eden Saha Türkleri arasında, Ayı Töreni de devam edegelen geleneklerden birisi olarak karşımıza çıkmaktadır.

Hantı-Mansi Topluluğu: Hantı ve Mansiler, Orta Rusya'da Ob Nehri havzasında yaşayan Batı Sibirya topluluğudur. Bugünkü toprakları, Ural'ın doğusunda, Ob Irmağı ve kolları boyunca uzanır (Vorobeva vd. 2015: 108-109). Günümüzde yok olmaya yüz tutan topluluklardan birisi olarak kabul edilen Hantıların bulunduğu 523.100 metrekarelik Hantı-Mansi Özerk Bölgesinin nüfusu, 2002 yılı sayımlarına göre 1.432.817'dir. Bu nüfusun 210.534’ü ise Türk uyruklu olarak kayıt altına alınmıştır (Saarniit 2011: 1, Yiğit 2006: 81). Hansi-Mansiler her ne kadar Ural koluna mensup bir dil konuşsalar da, binlerce yıldır Türklerle iç içe yaşamış, onlarla önemli kültürel alış verişlerde bulunmuş; dolayısıyla ortak özellikler gösteren bir topluluktur. Tarihçilerin genel görüşüne göre, Mansi, Hantı ve Ugor kavimleri eskiden Ural'ın batı yakasındaki İdil boylarında yaşamaktaydılar. Daha sonra Doğu Avrupa'dan yapılan göçler nedeniyle Ugorlardan bazı boylar, kuzey doğuya; Magyarlar 
ise güney ormanlık alana doğru kaydılar (Rasonyi 1993: 77-78). Günümüzde Rusyànın içinde yaşayan halklar arasında yer alan Hantı Mansiler, Orta Asyảnın zorlu yaşam şartları nedeniyle, tıpkı Türk kavimler gibi kışlak ve yazlak prensibine göre yaşamışlardır.

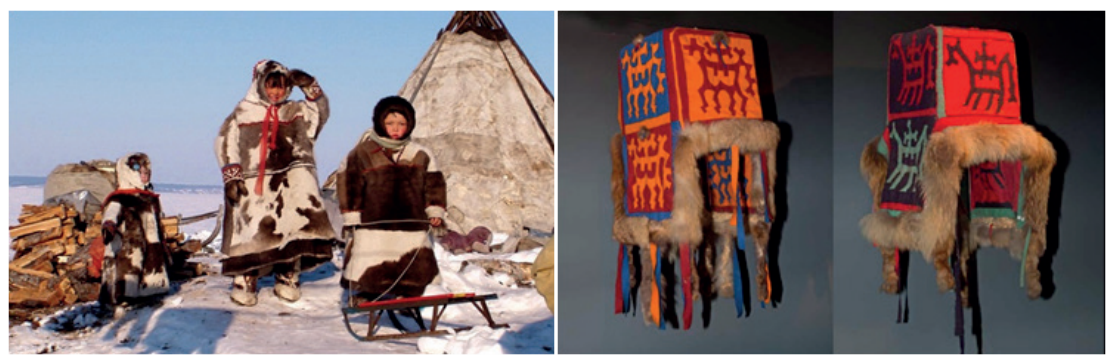

Resim 4. (solda) Hantı Mansilere ilişkin günümüzden bir görünüm (kulturologia.ru) Resim 5. (sağda) Törenlerde Kullanulan Başllklar (Khanty Bear Festival Kazym Siberia Part 1)

Mansiler, ağaçlardaki yaban arısı kovanlarını aile tamgalarıyla işaretliyorlar; etleri tütsüleyerek, güneşte kurutuyorlardı. Hanımlar, zevkli ve renkli nakışlar işliyor, süslemeler yapıyor, renkli yünler dokuyor, cam boncuklardan süslemeler yapiyorlardı (Vorobeva 2015: 110). Forsyth, "Bu sanat muhtemelen komşuları Türklerden Fin Ugorlara geçmiştir" demektedir (Forsyth 2006: 13). Artık stilize hale gelmiş tamgalarını, çeşitli eşya ve kıyafetlerinde görmek mümkündür (bk. Resim 5). Hantı ve Mansilerin sadece gündelik yaşamları değil, inanışları da Türklerle çok büyük benzerlikler göstermektedir. Tıpkı Eski Türk İnanışına dâhil olan Türkler gibi, Hantı-Mansi topluluğunda da kamlar önemli bir konuma sahiptir. Eski dönemlerde geyik, at veya diğer hayvanlardan, kutsal ağaçlar altında tanrıya kurbanlar kesiliyor, kurbanın kanı kam tarafından insanların alınlarına sürülüyordu. Bazen kurban törenleri mezarlıklarda da yapılabiliyor; ölenlerin mezarına özel eşyaları konuyordu (Forsyth 2006: 15). Bilindiği üzere ölenlerin özel eşyaları ile birlikte gömülmesi, yani kurgan geleneği, Türklerin de çok eski bir âdetidir.

Hantı ve Mansilerde her boyun simge olarak kabul ettiği bir hayvan vardı. Bunlar, geyik, kartal, kunduz, kaz gibi farklı hayvanlar olabilirdi (Vorobeva 2015: 110). Geçmişte hayvanların avlanmasını, doğaya saygı çerçevesinde ihtiyaç gözeterek yapan Hantı-Mansiler, özellikle totem olan hayvanların avlanmasından kaçınıyorlardı. Ayı Bayramı diye de bilinen ayıların ruhunu kutsamak için yapılan ibadet, bütün Sibirya yerlileri tarafından bilinse de, özellikle Hantı ve Mansiler tarafından gerçekleştirilmekteydi (Forsyth 2006: 
15). Müzikteki yetenekleri bakımından dikkat çeken Hantı - Mansiler, müziği törenlerinde vaz geçilmez bir unsur olarak kullanmışlardır. Onlar için Ayı Töreninin ise bambaşka bir yeri ve anlamı vardır.

Nenetsler ve Nivhler: Nenets ya da Nenetler, yaşamakta olan Samoyed topluluklarının en büyüğüdür. Nüfusları gittikçe azalan Nenetsler, ağıllıklı olarak Yamalo-Nenets Otonom Bölgesinde yaşamaktadırlar. Ural-Altay dil grubunun Ural koluna mensup bir dil konuşurlar. Bu dil, UNESCO tarafindan tehlike altında ve kaybolmakta olan diller sınıfına dâhil edilmiştir (http://www.helsinki.fi). Ural kolunda Samodi diller ailesine dâhil olan Nenets dilinde "köçmek, göçebelik yapmak" anlamına gelen kaslatsya kelimesi kullanılmaktadır. Bu kelimenin kökünün kas-koçkoş şeklinde görünmesi gibi durumlar, Nenets dili ve Türk dillerinden Hakasça arasındaki benzerliğine işaret etmektedir (Efendiyeva 2003: 50). Liarskaya (2009: 33), Nenetslerin XX. yüzyılın başında, Yamal Yarımadasında göçebe olarak yaşadıkları bilgisini aktarmaktadır. Burada sözü edilen göçebelik, tıpkı Türk tarihinin de yanlış yorumlanması gibi yazın yazlaklara, kışın kışlaklara taşınma olmalıdır.

Animistik inançlar, Nenetsler arasında halâ varlığını sürdürmektedir (Hoppal 2001: 215). Nentslerin büyük önem verdiği ateş kültü ve ateşe zarar vermemeye yönelik tutumları, Eski Türk İnancı ile paralellik göstermektedir. Aşağıda tören yapan bir Nenets şamanı görülmektedir. 2002 nüfus sayımına göre Yamolo-Nenets Bölgesindeki 507.006 kişiden 55.343'ü Türk uyruklu olarak belirtilmiştir (Yiğit 2006: 81). Buna ilaveten yerli halk olarak kabul edilen Nenetslerin, Türk kültürü ile yakınlı̆̆ı aşikârdır.
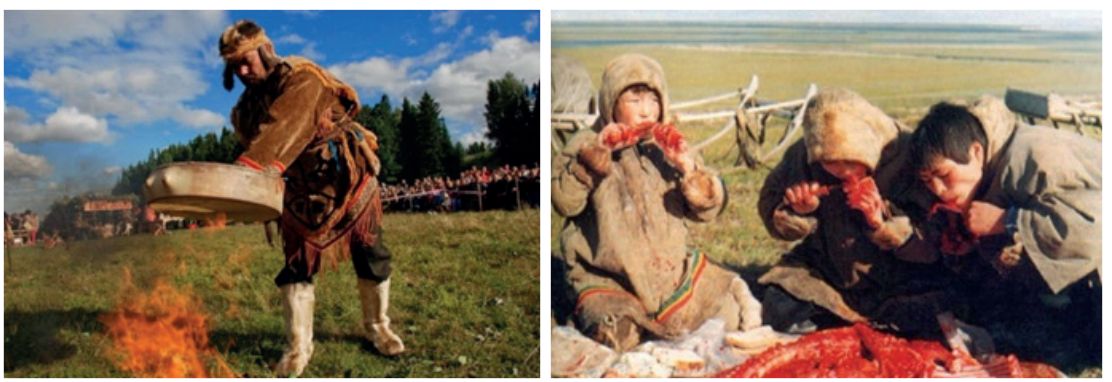

Resim 6. Nenets Şamanı Resim 7. Çiğ et tüketen Nenetslerden bir görünüm (biligbitig. com/2014/07/nenets-people.htm; Ненецкий автономный округ, vokrugsveta.ru) 
Ayı töreni geleneğinin görüldüğü bir başka topluluk olan Nivhler (Nivhks - Gilyaklar) ise Rusya Federasyonu'na bağlı Habarovsk Krayı bölgesindeki Amur Nehri'nin denize döküldüğü kısımda yaşayan ve Nivhçe konuşan bir halktır. Genellikle balıkçılık ve avcılık ile geçimlerini sağlayan Nivhler, yazın yaylaklarına, kışın ise kışlaklarına göçerler (Friedrich ve Diamond 1994: 10). Nivhlerin folklor ve müziğinde animizme dayanan pek çok unsur yer alır. Nivhlerin hayatında Şaman ayinleri, halk ezgileri, yüksek sesle sinyal amaçlı çalgıların kullanımı, ağıtlar, enstrümantal müzik, doğaçlama söylenen şarkılar çok önemli bir yere sahiptir. Ayı töreni de Nivhlerin hayatında son derece önemlidir (Mamçeva 2010: 10). Nivhler, yakın zamana kadar geleneklerine göre giyiniyor ve yaşıyorlardı. Ancak son zamanlarda bu özelliklerini yitirmeye başlamışlardır (Liarskaya 2009: 34-35).

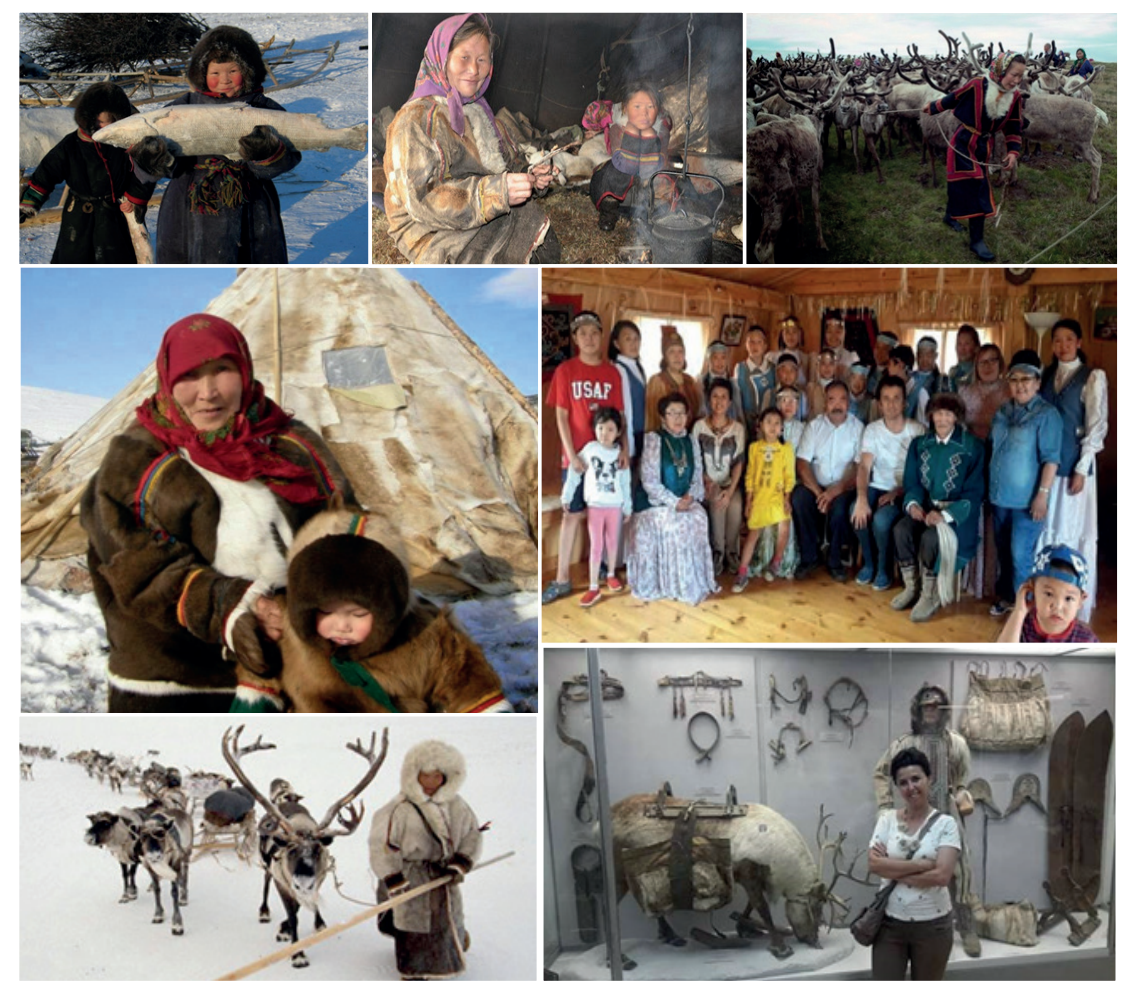

Resim 8-14. Nenets, Nivh ve Sahalarn Hayatından Görünümler

(Fotoğraflar: Ямало-Ненецкий автономный окру, naurfo.ru; gerasim.turbina.ru; kişisel arşiv) 


\section{Ayı Kültüi}

Ayı motifi, Türk mitolojisinde önemli bir yer tutmaktadır. Son zamanlarda yapılan araştırmalarda, Türkler ve çevrelerindeki topluluklarda görülen orman kültürünün, Türk mitolojisindeki ayı kültü ve simgeciliği ile bağlantısı ortaya konmuştur (Çoruhlu 2002:140). Türk topluluklarının (orijinal kaynak: göçebelerin) yaşadığı yerlerde ele geçen eserlerin üzerinde, sık sık ayı motifi ile karşılaşmak mümkündür (Kimball, Basilov ve Yablonsky 1995: 114). Türklerde Kamların kıyafetlerine ayılardan alınmış parçaların dikilmesi makbul sayılmıştır. Kamın göğe yaptığı yolculuk sırasında ona yardımcı olan ruhlar içinde ayı ruhu da yer alır. Ayrıca bazı Türk topluluklarında ayının avlanarak etinin yenilmesiyle, gücünün insana geçtiğine inanılmıştır (Çoruhlu 2002: 140, Nikolayeva 2015). Ayının gücüne duyulan hayranlık ve doğa güçlerine karşı hissedilen saygı, Sahalar ve onlara yakın coğrafyalarda bulunan bazı topluluklarda, ayı kültü temelli “Ayı Töreni” nin doğmasına neden olmuştur.

Saha'da görüşme imkânı bulduğumuz folklorist Ludmila Effimova, ayının kendileri için önemli bir ongun olduğunu ifade etmiştir. Ayının ruhunun kutsanması için yapılan törenin Saha kültürünün eski bir geleneği olduğunu, günümüzde de ayıya duyulan saygının devam ettiğini belirtmiştir (KK1). Bu saygı, çalgıların üzerine ayı figürünün resmedilmesi şeklinde kendisini gösterebilmektedir. Aşağıda solda elle ya da tokmakla çalınan vurmalı bir çalgı yer almaktadır. (Khataliev ve Khatyleva 2015: 96). Eğilmiş bir dala ipler vasıtasıyla bağlanan deri üzerine ayı resmi çizilen çalgı, Ayı Törenlerinde kullanılıyor olabilir. Güney Sibirya Türkleri arasında da ayının önemli bir ongun olduğu müzikolog Süzükei ve Kırgız tarafından ifade edilmiştir (KK2, KK3). Aşağıda sağda Sibirya Türk müziği konusunda önemli çalısmaları bulunan Süzükei ile görüşmemizden bir kare yer almaktadır.
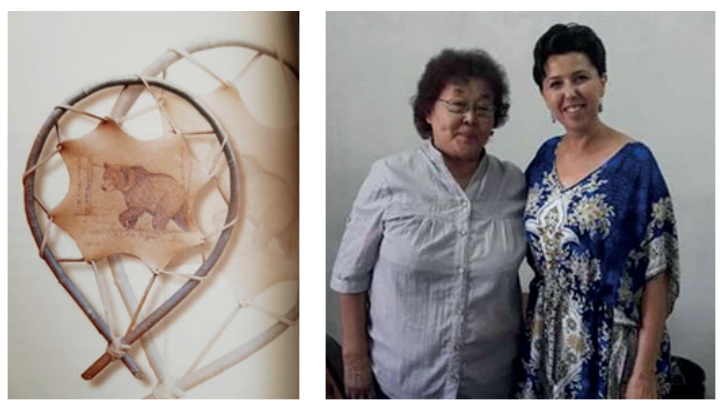

Resim 15. Ayı Resimli Vurmalı Saha Çalgısı Resim 16. V. Süzükei ile görüşme sonrası 
Baştanbaşa Sibirya yerlilerinde kahverengi ayı, totem kabul ediliyor ve halk bu hayvana büyük saygı gösteriyordu. Kahverengi ayı, hak ve adaletin simgesi, ormanın sahibi sayılıyordu. "Ayı" adının doğrudan söylenmemesi gerektiğine inanılıyor; ayı kelimesi yerine "pençeli yaşlı adam" gibi kelimeler kullanılıyordu. Sibirya halkları arasında ayı avlamaktan kaçınılırdı. Ancak Ayı Bayramı diye de bilinen ve ayıların ruhunu kutsamak için yapılan ibadette ayı avlanırdı (Forsyth 2006: 15, KK2). Bu ilginç töreni anlamak için, Türklerin ve Sibiryada yaşayan diğer halkların "ayı" figürüne duydukları saygı ve yükledikleri göstergebilimsel (semiotic) anlamları iyi çözümlemiş olmak gereklidir. Orta Asya’daki bazı Türk topluluklarında ayı için kullanılan sözcüklerin bir kısmının "ata” anlamına gelmesi, bu hayvana yüklenen değeri göstermektedir.

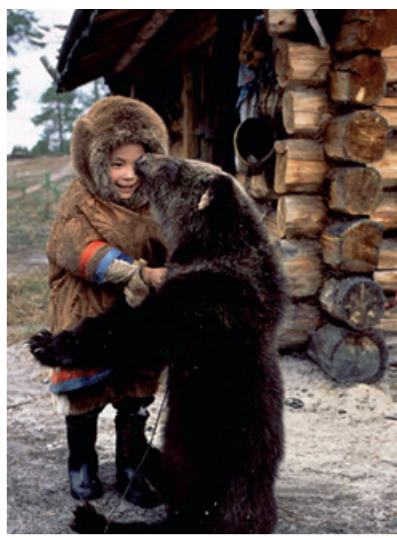

Güney Sibirya yerlisi Türk halklarından Hakas ve Şorların ayı ata anlamına gelen "aba", "dede" anlamına gelen "apsah/apşah” sözcükleri kullanmaları bu kültün bir yansıması olarak değerlendirilebilir. Bu kelimelere K. M. Pataçakov’un Hakasların kültür ve yaşamına ilişkin eseri vasıtasıyla aydınlanmak mümkündür. Örneğin aпcax (apsah) = дедушка (dede) (Pataçakov 1958: 86). Örnekleri arttırmak mümkün olsa da, asıl konumuz olan ayı törenine geçmek amaciyla burada bu kadar bilgi vermekle yetinilecektir.

Resim17.Küçük bir Hantı ve yavru bir ayının dostluğu (etnic.ru)

\section{Ayı Töreni}

Sibirya'da yaşayan Hantı Mansi, Saha Türkleri, Nenets, Nivh, Aşağı Amur bölgesi halkları arasında görülen Ayı Töreni, yüzlerce yıllık bir geleneğin devamıdır (Dimitrieva 2013: 154). Benzer uygulamalar, Japonya’nın kuzeyinde yaşayan Ainular, Kuzey Karadeniz, Kafkaslar, hatta Amerika'da da görülmüştür. Bu benzersiz kültürel olay, mağaralarda bulunmuş olan ve özel şekilde gömülmüş ayı kafatası ile kemiklerini temel aldığımızda, erken Paleolitik döneme kadar uzanır (Sokolova 2002: 41).

Sovyet Rusya döneminde tıpkı kam davulunun kullanılmasının yasaklanması gibi, Ayı Töreni de yasaklanan unsurların içinde yer almıştır. Ayının öldürül- 
mesi ve sonrasında gerçekleştirilen ritüeller yasaklandığı gibi, Ayı Törenine katılanlar 10 yıla kadar hapis cezasına mahkûm edilmişlerdir ${ }^{3}$. Bu yasaklar, 1980'lerden sonra Mihail Gorbaçov döneminde yumuşamıştır (Saarniit 2011: 3, Glavatskaia 2001: 20-22). Ruslar, tıpkı Türk destanlarının yasaklanması gibi milli olan her şeye yönelik bu tutumlarıyla birlikte, ellerinde bulundurdukları topraklarda etnolojik ve müzikolojik çalışmalar da gerçekleştirmişlerdir. Bu çalışmalara giriş kısmında değinilmiştir.

Ayı Töreni konusunda araştırma yapan Rus biliminsanlarından Vasilev, bu geleneğin bozkırda yaşayan halkların hayvan kültü ve av geleneği ile ilişkili olduğunu belirtir (Vasilev'den akt. Sokolova 2002: 44-45). Nivh asıllı Rus etnograf Çuner Mihayloviç Taksami, söz konusu geleneği, aşağıda söz edilen efsaneye dayandırmakla birlikte, tören boyunca "ayı" temalı efsaneler, hikâyeler, masallar anlatıldığını ve yine "ayı" konulu danslar, müzikler yapıldığını, şarkılar söylendiğini vurgular (Taksami 1992: 157).

Dimitrieva (2013: 158), ayı töreninin temellendiği efsaneye ilişkin, iki yaygın varyant olduğunu belirtir. Efsanede anlatılanlar genel itibariyle şöyledir: "Tanrı Toruma’nın ${ }^{4}$ küçük oğlu bir ayıdd. Bu nedenle çok güçlü ve çevikti. Tanrı, yeryüzüne oğlunu gönderdi ve geyikleri öldürmemesi gerektiğini belirtti. Ama açlık nedeniyle bu kurala uyamayan oğul ayı, cezalandırılarak ölümlü hale geldi. Öldükten sonra da ruhu ölümsüz olarak kaldı”. Bu hikâyeye büyük değer veren Hantı Mansiler, "orman insanı" diye adlandırdıkları ayıya karşı büyük bir saygı beslemektedirler. Ayı Töreni, bu saygının bir ifadesidir. Birkaç gün süren ve çeşitli uygulamaların gerçekleştirildiği bu törende, zamanla ayı öldürülmemeye başlanmış; sadece geleneksel ritüellerin gerçekleştirildiği, dans ve müziklerin yapıldığı, farklı kostümler eşliğinde tiyatroların oynandığı bir özelliğe kavuşmuştur (http://national-travel.ru/asia/trad-asia/medvezhii-prazdnik.html, Sokolova 2002: 44, Mamçeva 2010: 20-24). Yakın zamana kadar, ayının öldürülerek yakalanması Hantı Mansi, Nenetsler, Saha ve Nivhler arasinda törenin temel unsuruydu. Bu topluluklardaki uygulamalarda yer alan ayının öldürülmesi, et pişirme gelenekleri, ayının kafatası, kemikleri ile yapilan uygulamalar ve takip eden ritüeller büyük benzerlikler göstermektedir (Dimitrieva 2013: 154, KK2).

Geleneksel ayı töreni, iki temel bölüme ayrılabilir. Bunların ilki, ayının avlanması, et ve kemiklerinin işleme tabii tutulması ve yenilmesini içerir. İkinci kısım ise bu törene özgü pandomimler, teatral oyunlar, danslar ve şarkıları 
barındırır (Sokolova 2002: 41, Dimitrieva 2013: 155). Bu dönemde tatil ilan edilir. Törenin ilk gününde avlanan ayının eti yenir. Hayvanın yenilen kısımları ile ilişkili olarak, farklı topluluklarda kısmen farklı adetler mevcuttur. Sadece Amur ve Saha halkları, kalbi ve karaciğeri çiğ yer, kanını içerler. Yine Sahalar ve Nivhler kalp, akciğerler, kaburga ve göğsü kavururlar. Erkekler ve kadınların yediği kısımlar da ayrı olabilmektedir (Sokolova 2002: 47).

Aşağıda V.D. Kosareva tarafindan fotoğraflanan Ayı Töreninden sahneler yer almaktadır.

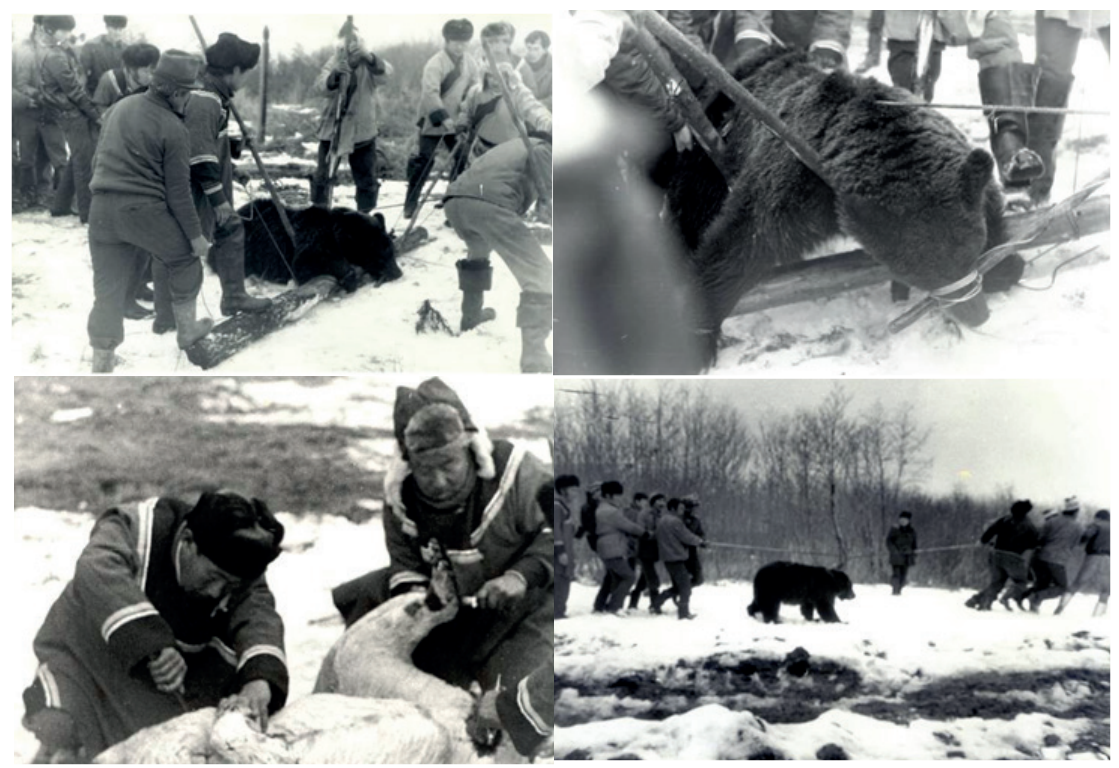

Resim 18-21. Ayı Töreni İ̧in Ayının Avlanması ve Öldürülmesi (Fotoğraflar: V.D. Kosareva)

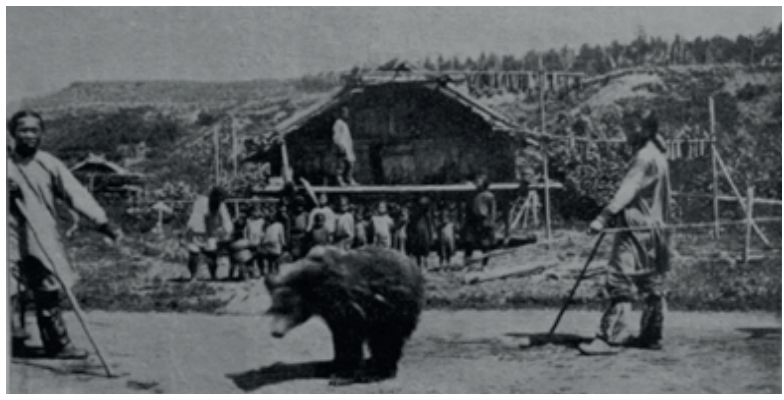

Resim 22. Ayz Töreni Nivh 1903 (http://sakhalin-museums.ru) 

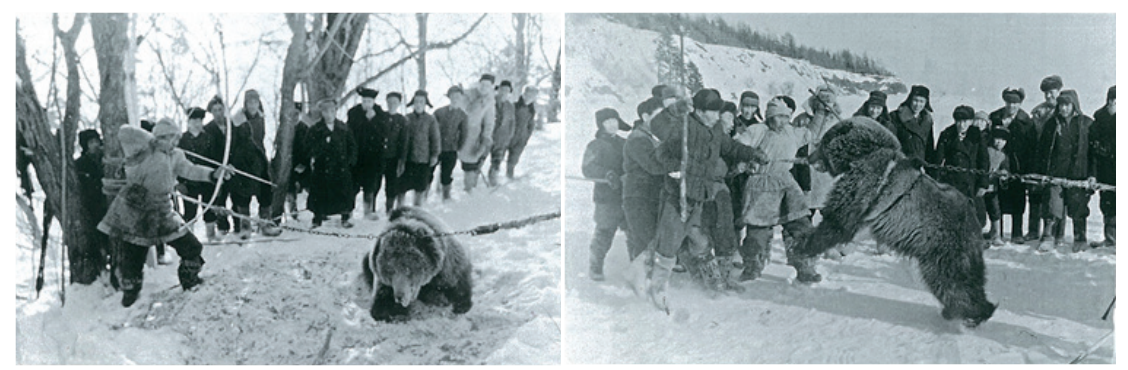

Resim 23-24. Ayı Töreninde Ayının Öldürülmesi (B.Brunner 2016)

Törende öldürülen ayının kemikleri ve kafatası genellikle ormana gömülür. Ancak bazen kafatası, ağaçlara asılabilmekte ya da evlerin tavan arasında tutulabilmektedir. Ayının pençeleri ve dişleri de uğur getirici olarak kullanılmıştır. Bazı yerlerde ayının göz ve burun deliklerinin üzerine para ya da küçük levhalar konulur. Amur halkları, ayının postunu ölmüş bir kişinin kıyafetleri gibi 40 gün saklarlar (Sokolova 2002: 47-48). Bu noktada Türk kültüründe en önemli sayılardan kabul edilen ve kutsallık atfedilen 40 sayısı dikkat çeker. Tıpkı bir insanın kırkının çıkması gibi, ayının da ölümünü takip eden kırk gün önemli görülür.

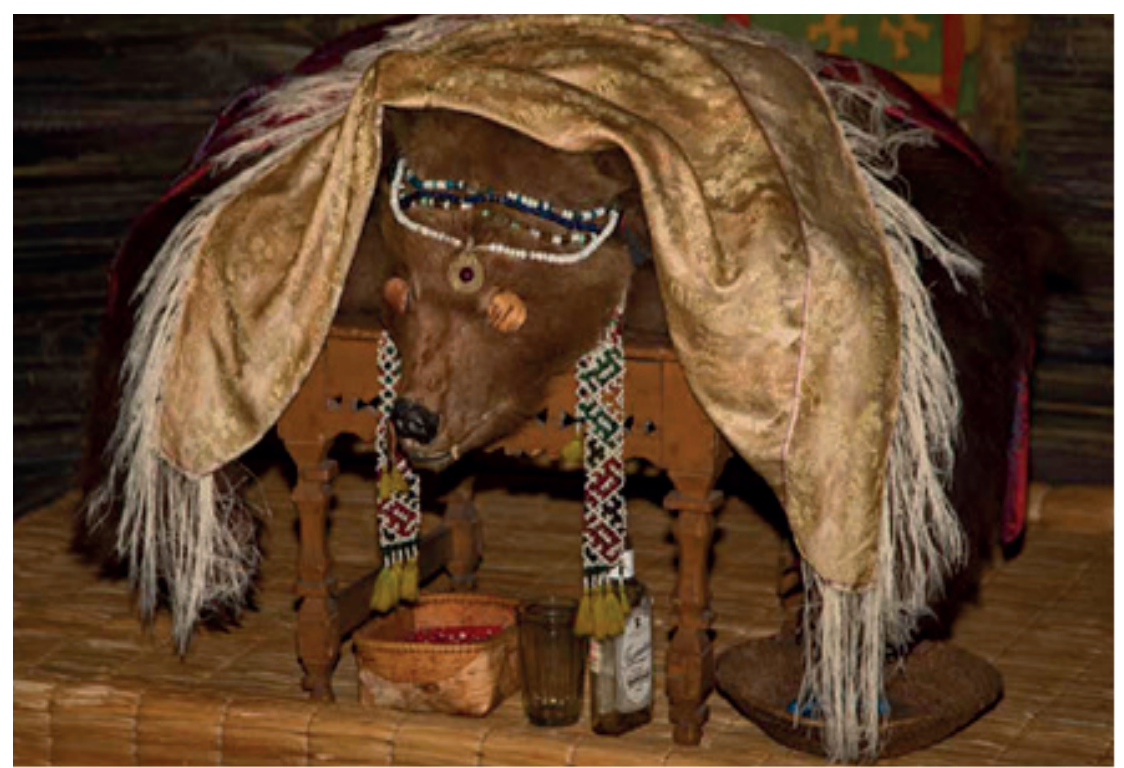

Resim 25. Gözlerine metal plaklar konuşmuş ayı postu. 2015 yılı Ayı Festivali (A. Björklund, Khanty Bear Festival Kazym Siberia, 2015: 35) 


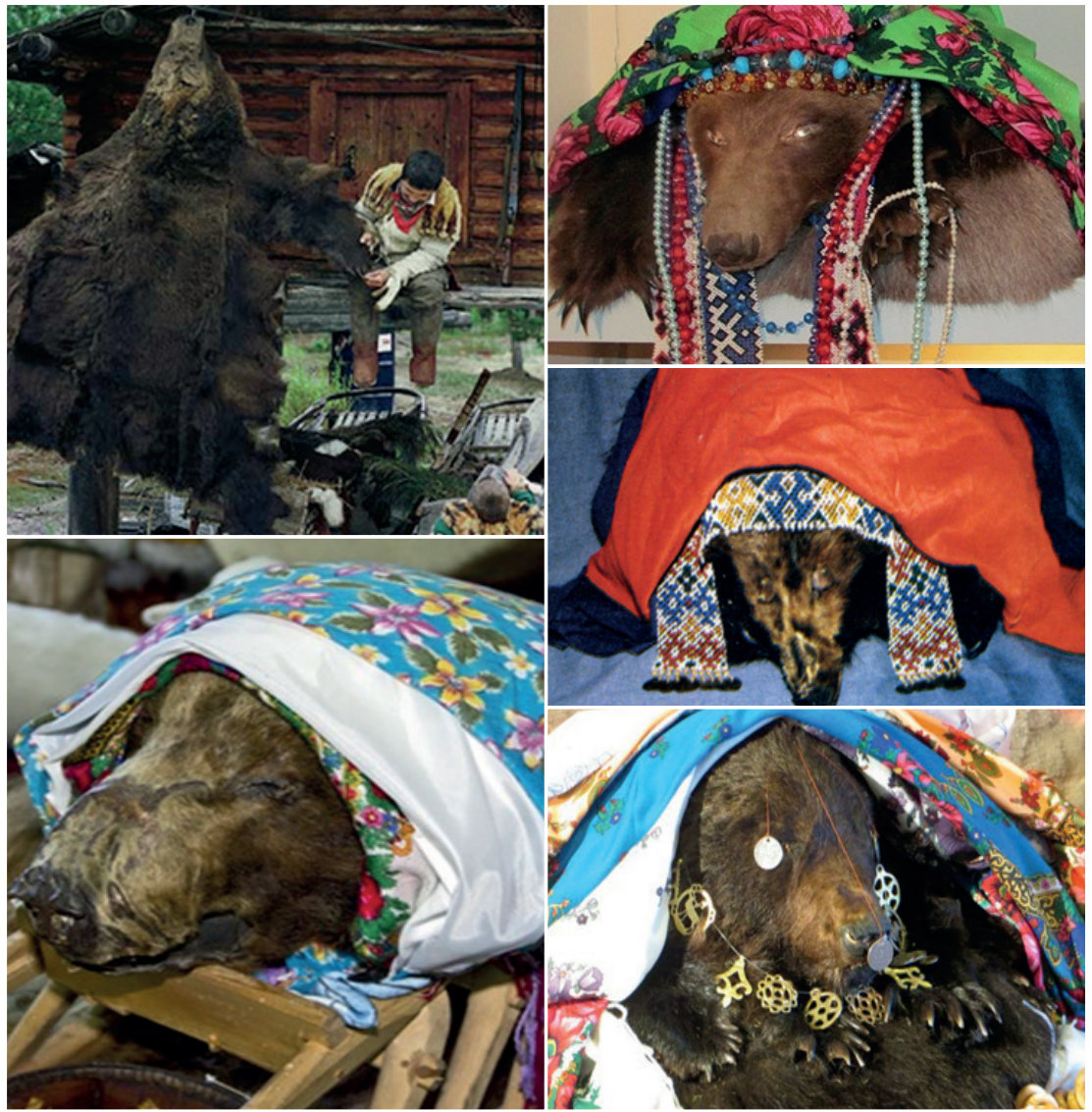

Resim 26-30. Ayının postunun yüzülmesi ve tören için süslenen ayı postu (national-travel.ru; yakutskhistory.net; nazaccent.ru; ugra.aif.ru)

Yukardaki örneklerde görüldüğü üzere, öldürüldükten sonra postu yüzülen ayı, tören için özenli bir şekilde hazırlanmaktadır. Başına geleneksel örtüler örtülen ayının gözleri, genellikle yuvarlak birer maden ile kapatılmaktadır. Ayı, boncuklarla, metal aksesuarlarla da süslenerek, tören için hazır hale getirilir. Aşağıda söz edilecek olan teatral oyunlar ve yine çalışmanın devamında detaylı şekilde değinilen müzikli ritüellerden sonra, törenin bitiminde ayıya saygı gösterilir. Buna ilişkin görünümler Resim 31 ve 32'de sunulmuştur. Burada 2015 yılında Hantı-Mansilerin düzenlediği Ayı Töreni’nden fotoğraflar yer almaktadir. 


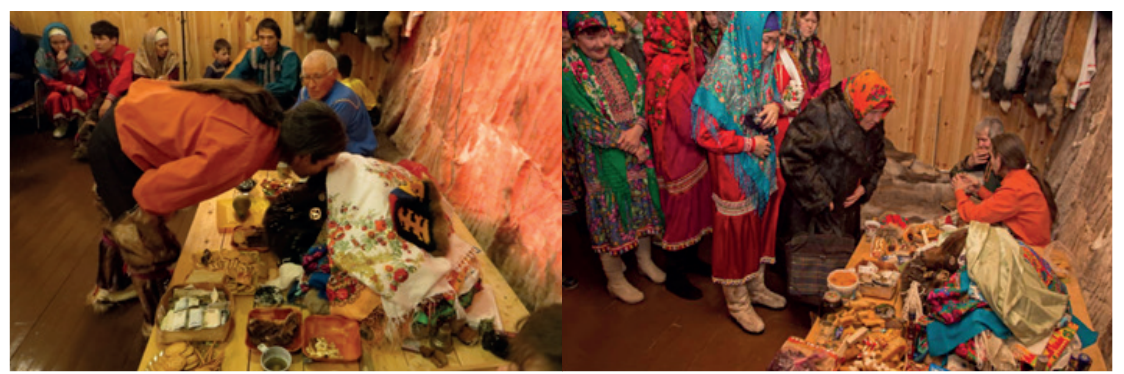

Resim 31-32. Ayzya Duyulan Saygz (Khanty Bear Festival Kazym Siberia, Part 2; ugra.aif.ru)

Ayı Festivalinde gerçekleştirilen uygulamalar ve törenin süresi, bölgeden bölgeye farklılıklar gösterebilmektedir. Törenin süresi 3 ila 7 gün arasındadır (Saarniit 2011: 2). Ayı törenine özgü ritüellerden birisi, "Su Besleme” olarak Türkçeye çevrilebilir. Kadınlar bu süreçte, özel anlamlara sahip yiyecekler hazırlarlar. Bunların içinde balık suyundan jöle ve çilek karışımlı bir yiyecek olan yukola sayılabilir. Kurban sürecine ise sadece erkekler katılır. Bu esnada ördek sürülerinin geçişi, baharın müjdecisi sayılır. Süslü elbiselerini giyen kadınlar, dikiş nakış gibi becerilerini sergilerler. Ayrıca törenlerde müzik yapmak da genellikle kadınların görevleri arasındadır (Fadeeva 2013 81-82). Kam davulu çalmak ise ekseriyetle erkekler tarafından yapılır. Törenin ayrılmaz parçalarından bir diğeri ise aşağıda detaylarına değinilen teatral oyunlardır.

\section{Ayı Töreninde Teatral Oyunlar}

Ayı Töreninde, hayvanların taklit edildiği ve hayvan maskelerinin kullanıldığı teatral oyunlar oynanır. Törende ahşap kılıçlarla yedi erkeğin yaptığı bir dans yer alır. Ayrıca kuş dansı da sergilenir (Sokolova 2002: 44). Bu dansın, Türklerin ve akraba / komşu toplulukların sahip olduğu hayvan kültleri ile bağlantısı açıktır.

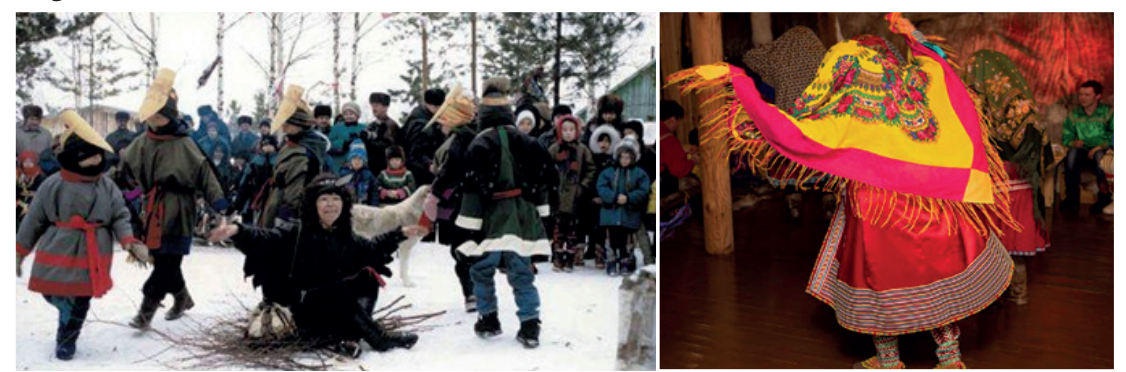

Resim 33-34. Kuşların Taklit Edildiği Oyun Esnasından (Khanty Bear Festival Kazym Siberia, Part 2; ugra.aif.ru) 
Daha önce de değinildiği üzere hayvanlara karşı duyulan sevgi ve saygı, Eski Türk İnanışının şekillenmesinde büyük bir yere sahiptir. Günümüzde bu inanışın devamı niteliğindeki Şamanizm törenlerinde, şamanın başta kartal olmak üzere çeşitli kuşları taklit eden kıyafetler giydiği görülür. Ayı Töreni sırasında da bu tarz kıyafetler giymiş kişilere rastlamak mümkündür. $\mathrm{Bu}$ törende gerçekleştirilen oyunlarda dikkat çeken bir başka unsur ise takılan maskelerdir. Aşağıda bu maskeler yer almaktadır. Siyah-beyaz resim 1969; diğer fotoğraflar 2015 yllına aittir.

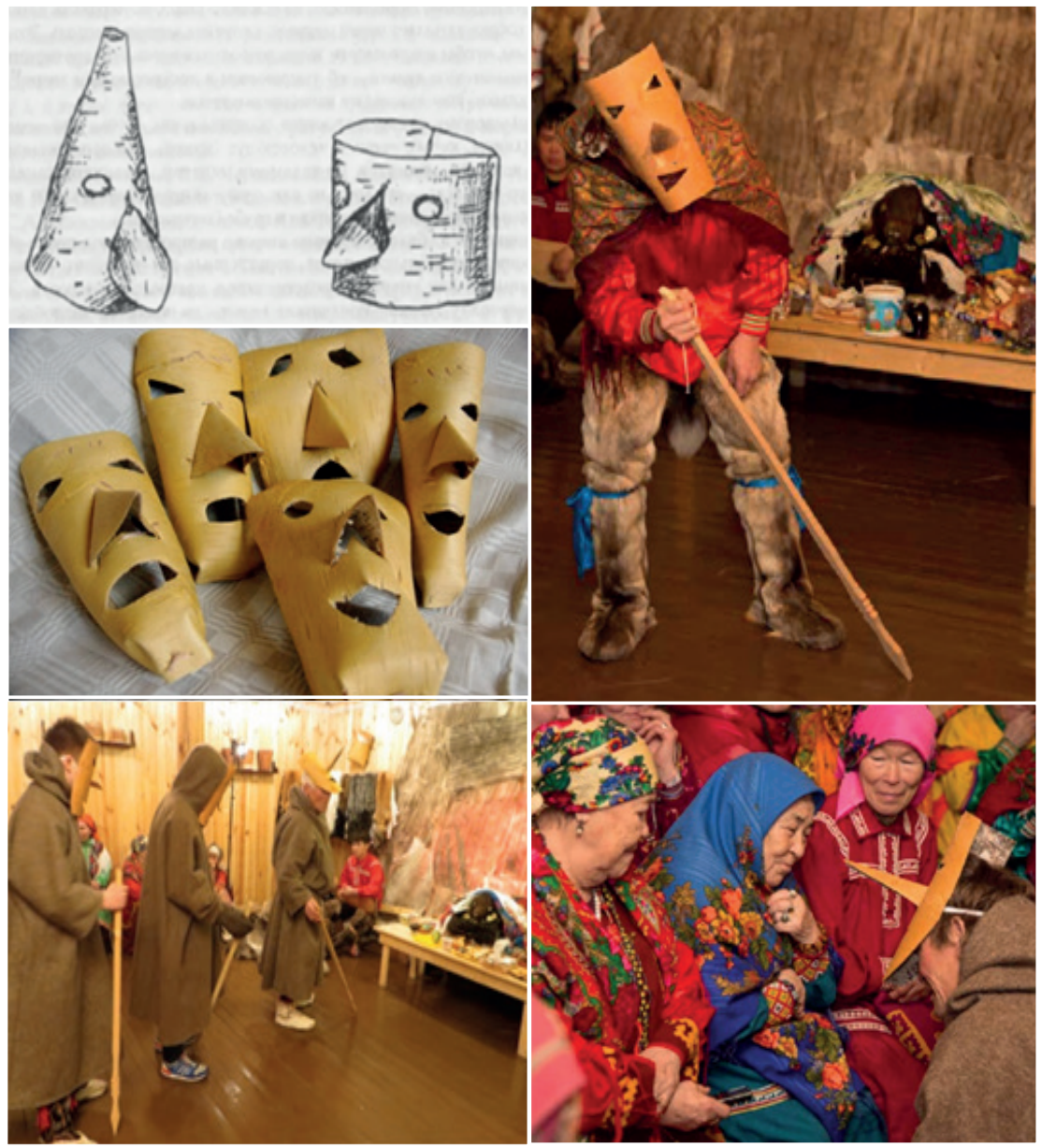

Resim 35-39. Ayı törenlerinden maskeler (Tobolsk Müzesi - Sokolova 2002: 47; Khanty Bear Festival Kazym Siberia, Part 2: 24-42; http://gotoural.com; ugra.aif.ru) 
Törende şarkıları söyleyenler, özel kostümler ve hayvan maskeleri kullanırlar; maskelerini taktıkları hayvanların davranışlarını taklit ederler. Kuzgunlar ayının ruhunu çalmak isteyen hırsızları oynamaktadırlar. İnsanlar da ölümsüz ruhu korumaya çalışırlar. Teatral şekilde geyik yavrusu kılı̆̆ındaki kurbanlar sunulur. Törende güreş, atlama, akrobasi yarışmaları da düzenlenir. Ayrıca kukla gösterileri ve atalar dansı yapılır (Dimitrieva 2013: 156-157, http:// national-travel.ru, Fadeeva 2013: 80, Sokolova 2002: 49).

\section{Ayı Töreninde Söylenen Şarkılar}

Çalışmanın başlangıcında Orta Asya Türklerinin düzenledikleri tören ve festivallerde müziğin önemine değinmiştik. Müzik, gerek eğlendirme işlevi, gerekse dini duygu ve durumları ifadedeki gücü bakımından hemen her türlü törenin vazgeçilmez unsuru olarak karşımıza çıkar. Bu çalışmanın temel konusunu teşkil eden Ayı Töreni için de durum aynıdır.

Saha Türkleri, Hantı-Mansi, Nivh ve Nenets'lerde görülen Ayı Töreni süresince çeşitli şarkılar söylenir ve enstrümantal müzikler yapılır (Väisanen'den akt. Saarniit 2011: 2). Bu törende müzik yapmak genellikle kadınların görevi olduğu için, şarkılar da kadınlar tarafından söylenir. Efsanede yer alan ayının öldürülmesinden dolayı duyulan üzüntüyü anlatan bu şarkılarda, insanların temsilcisi ayı övülür; ayının ölüşü ve tekrar dirilişini anlatan ayı döngüsü konulu şarkılar söylenir. Bu esnada şarkıcılar, yukarı kısımda söz edildiği üzere özel kostümler ve hayvan maskeleri kullanırlar. Ayının asıl temayı oluşturduğu şarkıların yanı sıra mitolojik olayları konu alan şarkılar da söylenir (Dimitrieva 2013: 156, Sokolova 2002: 49). Fadeeva, bu törende lirik şarkıların söylendiğinden söz eder (Fadeeva 2013: 82).

\section{Ayı Töreninde Kullanılan Çalgılar}

Ayı töreninde bazı çalgıların kullanılması, çok önemli bir gelenektir. Bu çalgılar öylesine önemlidir ki, öldürülen ayının ruhunun doğru yolu bulmasını sağlayacak seslerin, ancak bu çalgılar vasıtasıyla üretildiğine inanılır.

Şaman/Kam Davulu: Ayı Töreninde kullanılan temel çalgılardan birisi, şaman / kam davuludur. Bu uygulamaya ilişkin farklı bölgelerde değişiklik ritüeller mevcuttur. Bilindiği üzere Eski Türk İnanışında kamlar (şamanlar), din uluları olarak son derece önemli görevlere sahiptir. Günümüzde Şamanizm inanışı da bu inancın devamı niteliğindedir. Gelecekten haber veren, hastalıklara çare bulan, koruyucu ruhları çağıran, insanları kötü ruhlardan koruyan, kurban- 
ları gök ve yer tanrısına ulaştıran, ruhları ölüler âlemine gönderen kamın en önemli tamamlayıcısı kıyafeti ile birlikte davuludur.

Bazı ritüellerde davul, kamın göğe yükselmesini ya da yer altına inmesini sağlayan bir aracı, bineği (atı) vazifesini görür (Drury 1996: 76). Kam davulunun yapıldığı malzeme ve üzerine işlenen resimler, simgesel anlamlar içermektedir.

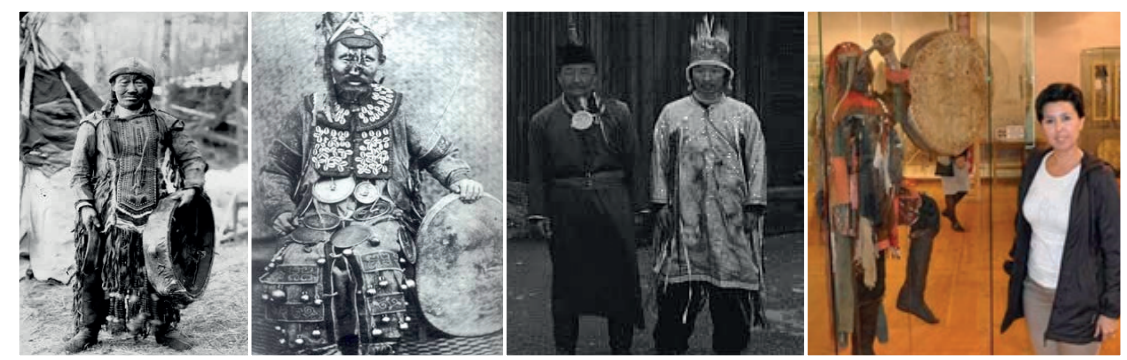

Resim 40-43. Çeşitli Bölgelerden Kamlar

Soldan iki fotoğraf kuzey Sibirya, sağdan iki fotoğraf güney Sibirya kamlar1 ve kıyafetlerini göstermektedir. Sağda Minusinsk Doğal Kültür ve Yaşam Müzesi'nde fotoğrafladığımız kam davulunun üzerinde Türk mitolojisine ait çizimler yer almaktadır. Kam elbiselerine demirden ayı figürlerinin asıldığı görülür. Buna ilişkin olarak Yakutistan Ulusal Müzik ve Folklor Müzesi’nde fotoğrafladı̆̆ımız kam kıyafeti güzel bir örnektir.
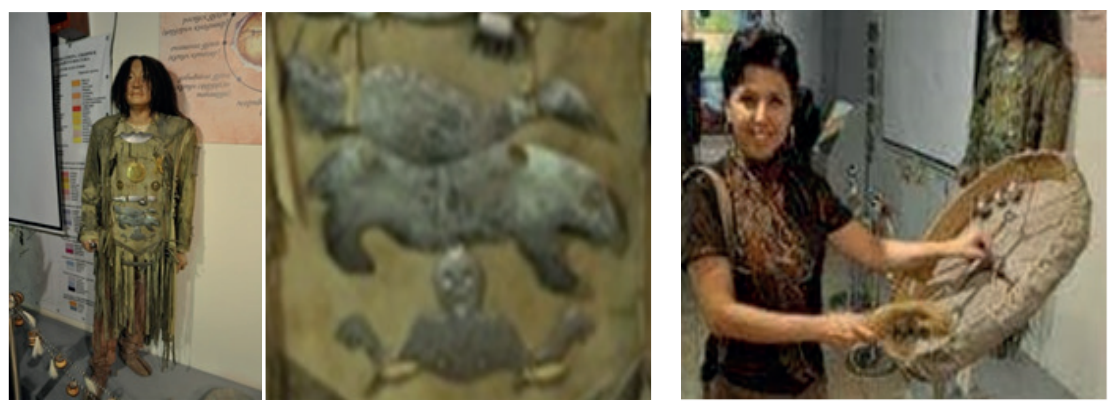

Resim 44. Saha Kam Elbisesi Üzerindeki Ayı Figürü (Kişisel Arşiv - Yakutsk 2017) Resim 45. (Sağda) Saha Kam Davulu ve Tokmă̆g (Kişisel Arşiv - Yakutsk 2017)

Kam davulunun malzemesi genellikle kutsal sayılan ağaçlardan yapılır. Türklerde davulun kasnağının yapıldığı ağaç, genel olarak kayın ve sedir ağacıdır. Kam davulunun kasnağı ve diğer malzemelerinin kayın ve sedir ağacından yapılması, onların kutsal anlamları ile ilgilidir. Kam davulunun kasnağı gibi davula gerilen deri ve tokmakta kullanılan malzeme de özenle seçilir. Yan- 
da Yakutistan Ulusal Müzik ve Folklor Müzesinde özel izinle elimize aldığımız kam davulu ve kutsal kabul edilen tavşan ayağından yapılmış tokmağı görülmektedir.

Kamlar ve başlıca araçları olan davullar, pek çok törende olduğu gibi Ayı Töreninde de yer alırlar. Bu törende müzik yapmak genellikle kadınlara verilen bir görev olsa da, kam davulu açısından bir istisna söz konusudur. Kam davulu ekseriyetle erkek şamanlar tarafından çalınmaktadır.
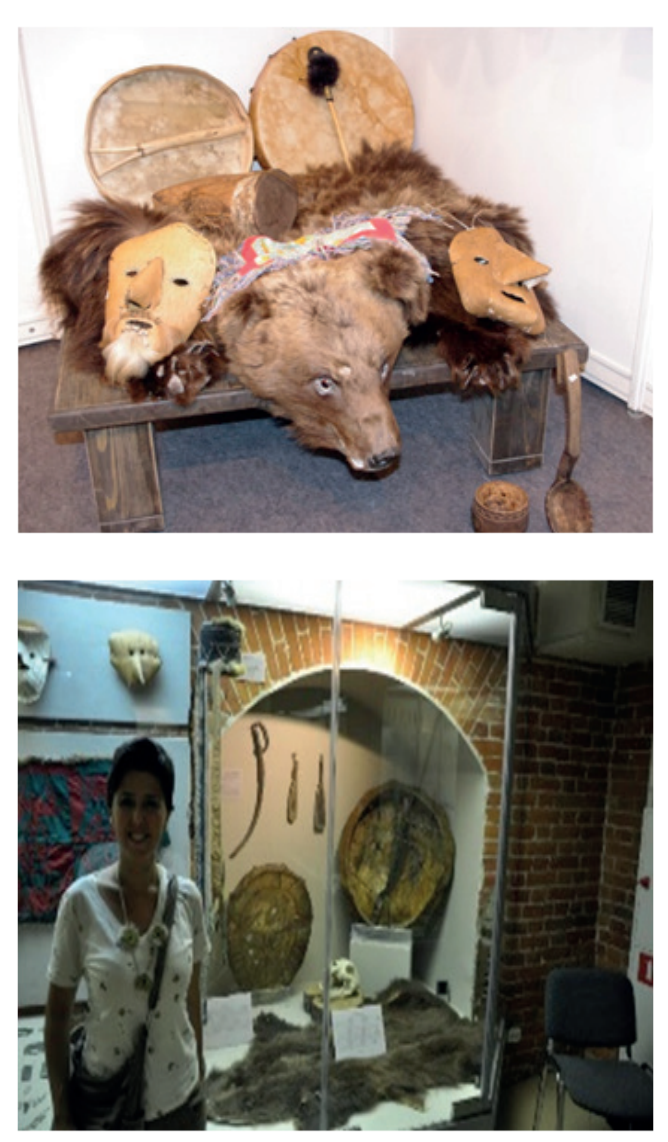

Resim 46. Ayı töreninde kullanılan malzemeler (http://gotoural. com)

Solda 2015 yilına ait bir fotoğraf yer almaktadır. Burada ayı töreninde kullanılan ayı postu, teatral oyunlarda ve şarkıcılar tarafindan takılan maskeler ile arka tarafta ayının ruhuna yol göstermek için çalınan şaman davulları görülmektedir.

Resim 47. Ays töreninde kullanılan malzemeler (Kişisel Arşiv Novosibirsk 2017)

Soldaki fotoğrafta Ayı Töreninde kullanilan maskeler, ayı postu, kam davulları görülmektedir. Novosibirsk Yerel Tarih ve Doğa Müzesi'nde çektiğimiz bu fotoğrafta, ayı postunun üzerinde ayı kafatası yer almaktadır. Ayı Töreni ile özdeşleşmiş bazı çalgılar vardır.

Ayıya verilen büyük önem ve değer, bazı bölgelerde kam davullarının ayı derisinden yapılmasına neden olmuştur. Örneğin Doğu Hantı'da, Kamın kıyafeti ile davul tokmağı, ayı derisinden yapılmaktadır (Sokolova 2002: 49). 


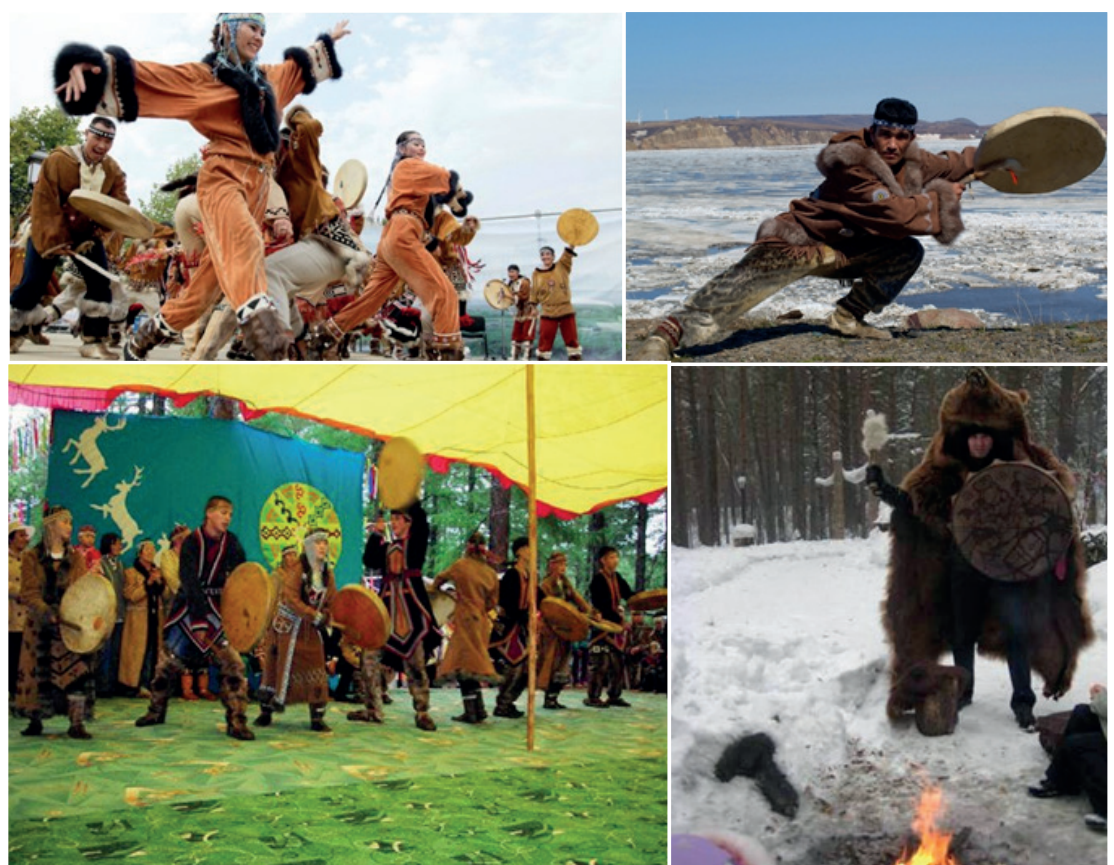

Resim 48-50. Ayı Töreninde Çalınan Şaman Davulları (biblioteka15.ru; national-travel.ru)

Yukarıda tören esnasında davul çalarak dans eden kişiler görülmektedir. Resim grubunun sağ altındaki fotoğrafta ise, Ayı Töreninde üzerine ayı postu giyerek davul çalan bir şaman yer almaktadır. Ayı Töreninin hayvan ruhları ve Şamanizm ile olan bağları, Şamanların başlıca çalgısı davulun, bu törenin vazgeçilmez unsuru olmasını sağlamıştır. Ancak bir başka vurmalı çalgı, bu tören söz konusu olduğunda daha da dikkat çekicidir. Brevne adı verilen vurmalı çalgıya ilişkin bilgiler aşağıda sunulmuştur:

Brevne / Çastirge: Müzikal bloklar (музыкальном бревне) olarak da anılan "brevne"/"çastigre" çalgısı, Ayı Töreni ile özdeşleşmiştir.

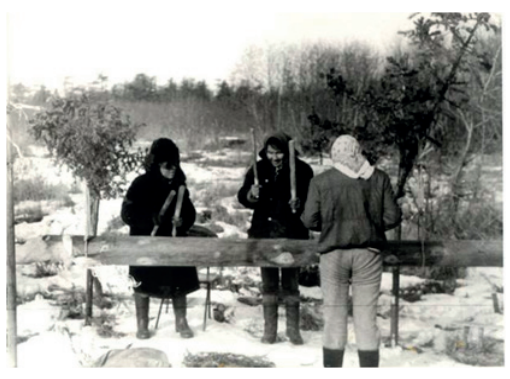

Resim 51. Brevne / Çastirge çalan kadınlar

Ayı Töreninde kadın ve erkeklerin farklı görevleri vardır. Kadınların işleri arasında yemek hazırlamak, teatral danslara katılmak ve müzik yapmak bulunur. Brevne/çastigre ismi verilen çalgı da sadece 
kadınlar tarafından çalınır. Törendeki hemen hemen tüm olaylara, ritüelle ilgili danslara eşlik eden bu çalgı, karaçam veya ladin ağaçlarından yapılır. Çalg1, 5-6 metre uzunluğundaki bir ağaç kütüğünden oluşturulur. Kütük, iki tarafından iplerle askıya alınır. Böylece yerden 100-120 cm kadar yukarı kaldırılmış olur. Bunların, içi kabaca oyulmuş olanları da vardır. (Fadeeva 2013: 80, Mamçeva 2010: 48).
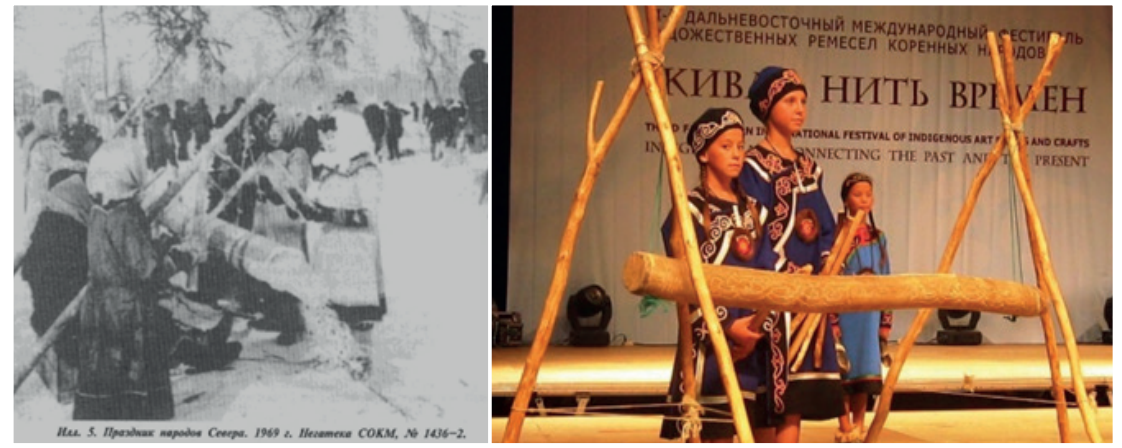

Resim 52. 1969 yılı Ayı Töreni (N.A.Mamçeva); Resim 53. 2015 yılı Ayı Töreni

Çalgı, ellerinde ikişer çubuk tutan birkaç kadın tarafından çalınmaktadır. Çalgının sesinin ayının ruhuna yol gösterdiğine inanılmıştır (Fadeeva 2013: 80).

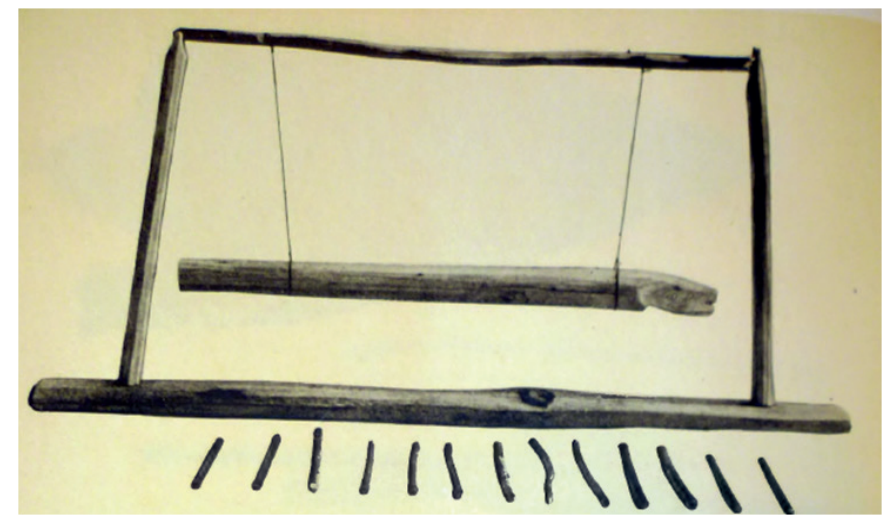

Resim 54. Brevne / Çastirge (Vertkov vd.1963)

Orta Asya Türk çalgıları üzerine son derece kıymetli çalışmaları olan Vertkov da çastirge' yi Ayı Töreninde kullanılan, ağaçtan yapılmış vurmalı bir çalgı olarak tanımlar ve küçük sopalar yardımıyla kadınlarca çalındığını ifade eder. Üstte Vertkov'un eserinde yer alan çalgının görseli sunulmuştur. 
Pagremuşka (Çıngırak) ve Ziller: Ayı Töreni boyunca, bu törene mahsus özel yiyeceklerin hazırlanması, özel şarkıların söylenmesi, çeşitli becerilerin sahnelenmesi sırasında çıngırak / pagremuşka adlı çalgı, yine kadınlar tarafından çalınır (Fadeeva 2013: 81-82). Kadınlar, davulların ritmine ellerindeki çıngıraklarla eşlik ederek dans ederler. Bu dans, ateşin etrafında gerçekleştirilir. Pagremuşka, büyük orman tavuğunun / çalıhorozunun (capercaillie) şişen boyun / guatr kısmından yapılır (http://sch-6.edusite.ru). İçerisine kum ve kemik parçaları konur ve sallanarak çalınır. Çalgı, çeşitli etkinlik ve festivallerde olduğu gibi Ayı Töreninde de kullanılır. Orman tavuğunun boynundan yapılan marakasların yanı sıra, balık derisi kullanılarak yapılan çıngırak tipi çalgılar da törende yer alabilir. Bu çalgılar çalınırken, kadınlar kollarını omuzlarından keskin hareketlerle sallayarak dans ederler (Mamçeva 2010: 62). Tören sırasında kadınlar, boyunlarına ses çıkartan çıngıraklı takılar da takarlar (Mamçeva 2010: 49).
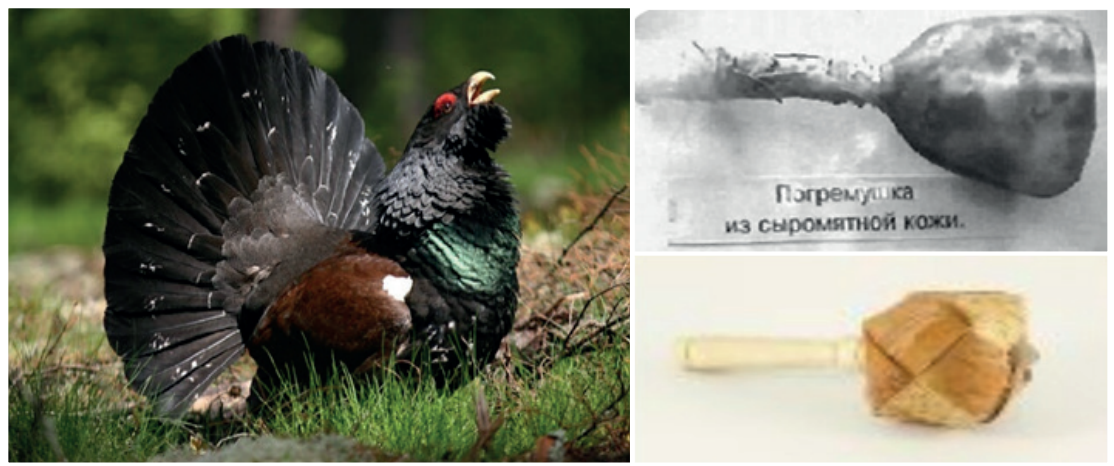

Resim 55. Pagremuşka çalgısının yapımında girtlak bölgesi kullanılan orman tavuğu Resim 56-57. Pagremuska örnekleri (Vertkov vd 1963; sch-6.edusite.ru)

Yukarıda solda geleneksel pagremuşkanın yapımında kullanılan dağ tavuğu görülmektedir. Bu hayvanın guatr kısmından yapılan pagremuşka üstte sağda; ağaç kabuğundan yapılan bir başka marakas tipi çalgı ise onun altında yer almaktadır. Pagremuşka kelimesi, marakas ya da çıngırak anlamında yaygın bir çalgılar topluluğu için de kullanılır. Aşağıda ise Saha (Yakutitan) Cumhuriyeti ve Tuva'da dağ tavuğu örnekleri görülmektedir. 


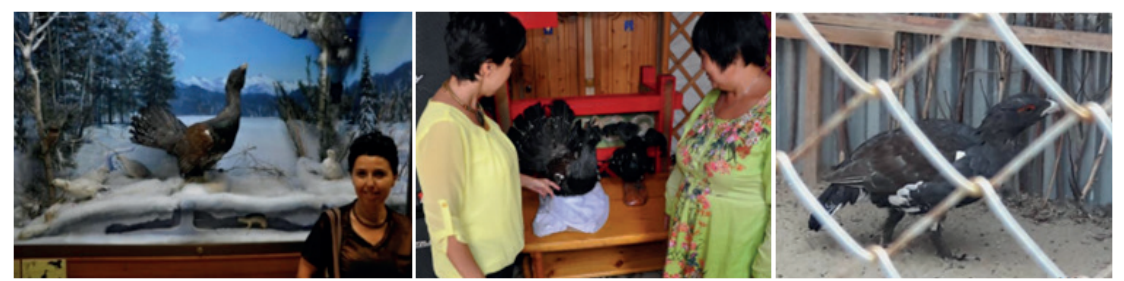

Resim 58. Yakustistan Doğal Yaşam Müzesinde doldurulmuş dă̆ tavuğu (Kişisel arşiv - Kızıl 2017)

Resim 59. Tuva'da doldurulmus dă̆ tavuğu (Kişisel arşiv - Kızıl 2017)

Resim 60. Yakutsk Hayvanat Bahçesinde canlı dă̆ tavŭ̆u (Kişisel arşiv - Yakutsk yakınları 2017)

Titra: Geleneksel Ayı Törenlerinde brevne, davul ve çıngıraklar kullanılırken, günümüzde kanuna ve gitara benzeyen bir çalgı olan titra da çalınmaya başlanmıştır (Sokolva 2002: 49). Bu daha yeni bir gelenek olmalıdır. Titra, ahşap bir kasnağın üzerine 17-45 arasında değişen tel sayısına sahiptir. XVIII. yüzyıl Almanya’sı ve Avusturya’sında çok sevilen bir çalgı olan titranın, gitarı andıran bir sesi vardır.
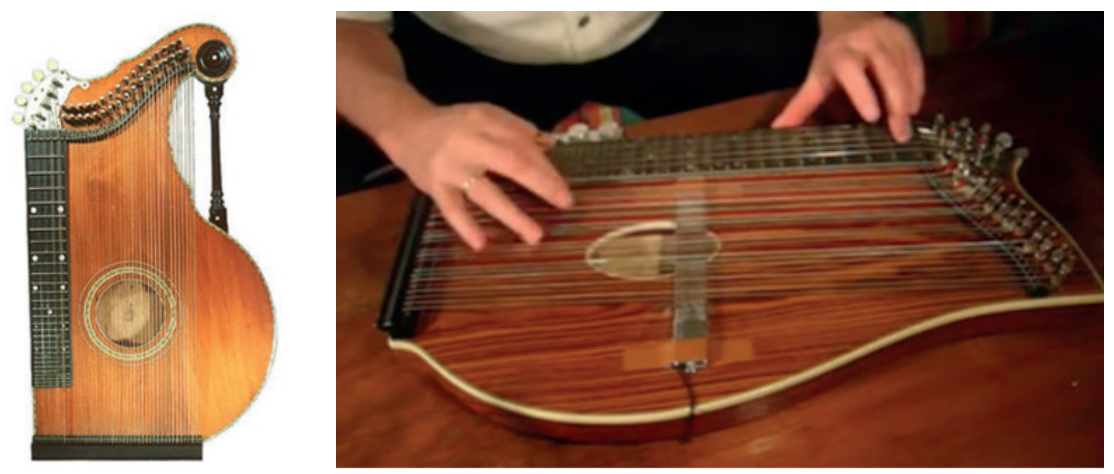

Resim 61-62. Titra Örnekleri

Nars-yuh: Ayı törenlerinde danslara nars-yuh ile de eşlik edilmektedir (Sokolova 2002: 49). Orta Asya Türkleri arasında çok sevilen “yatağan”a benzer bir çalgı olan nars-yuh, yatagan gibi yere yatırılarak değil, arkası karna gelecek şekilde tutularak çalınmaktadır.

Yaklaşık 1 metre uzunluğundaki bu çalgının telleri, geyik bağırsağından ya da tendonlarından yapılmaktadır. Hantı-Mansi'de yaygın olarak kullanılan çalgı, genellikle beş tellidir (Vertkov vd. 1963: 146). 

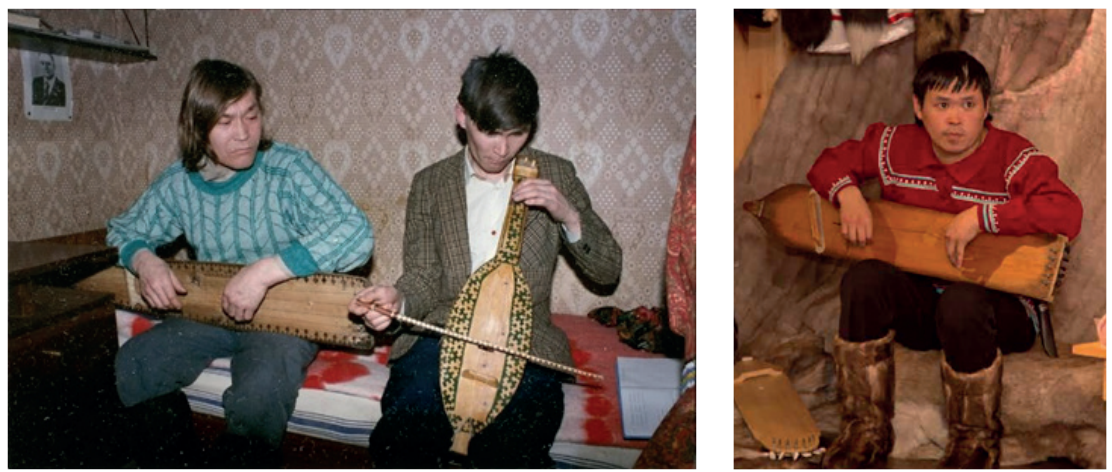

Resim 63. (Altta solda) Hantı Mansi'lerin nars-yuh ve narkis-yuh icrası

Resim 64. (Altta sağda) 2015 ynlı Ayı Töreninde nars-yuh icrası (Khanty Bear Festival..2, 2015: 32)

Kahramanlık şarkıları, nars-yuh eşliğinde söylenmiştir. Nars-yuh, Ayı Törenlerinde dans edenlere de eşlik eder. Bu çalgının sesinin hem insanları, hem de kuşlarla diğer hayvanları büyülediğine inanılmıştır. Çalgıya bu nedenle Tanrının şarkısı / sesi de denilmiştir (http://sch-6.edusite.ru: 10).
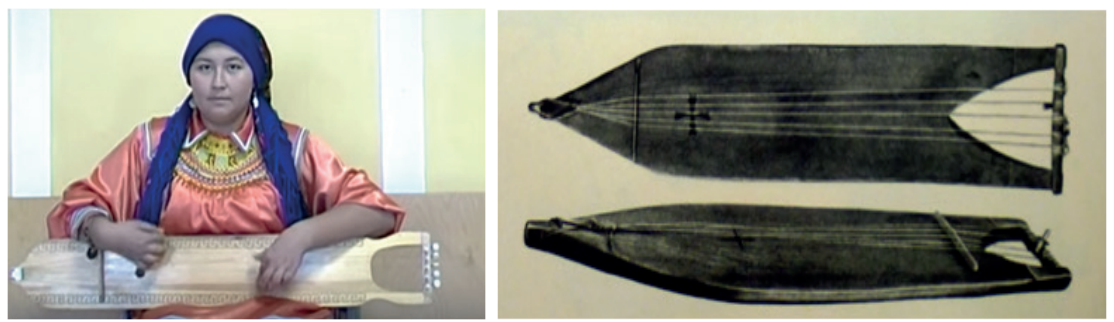

Resim 65. Nars-yuh çalan kadın (sch-6.edusite.ru)

Resim 66. Nars - yuh (Vertkov vd. 1963: Ek 735)

Ayı Törenlerinde, nars-yuh çalınırken, dansçılar, kuş, sinek, balık gibi hayvanların hareketlerini taklit ederek dans ederler (Vertkov vd. 1963: 146).

Sungultap: Kaynaklarda sungultap adlı çalgının da Ayı Törenlerinde yer aldığı bilgisi vardır. Sangultap da nars-yuh'a benzeyen, iki elle çalınan bir çalg1dır. Geçmişte ayı törenlerinde çalınan bir çalgı olan sungultapın ismi, "sangkulya -сангкулья” “ауı оynatmak” fiilinden gelir (Vertkov vd. 1963: 145). Tellerinde nars-yuh gibi geyik bağırsakları kullanılıyor olmalıdır. 


\section{Sonuç}

Ayı Töreni, kendine has uygulamaları ile Türk kültürü ve Sibirya kültürü için son derece önemli bir yere sahiptir. Yüzyıllardır yapıldığı tahmin edilen bu tören, Sovyet Rusya zamanında bir süre yasaklansa da, bugün Saha (Yakut) Türkleri, Hantı-Mansiler, Nenets ve Nivhler arasında yaşatılmaya devam etmektedir. Bilhassa Saha Türkleri ile kültürel açıdan pek çok benzerliği bulunan ve Japonya’nın kuzeyinde yaşayan Ainular arasında da Ayı Töreni görülür. Hayvan ruhlarına karşı duyulan saygı ve Şamanizm kökenli bu törende, yakın zamana kadar bir ayının avlanması, törenle öldürülmesi, bazı bölgelerde kalp ve ciğerinin çiğ olarak yenmesi, çeşitli ritüeller eşliğinde etinin pişirilmesi, kemiklerinin gömülmesi gelenekleri devam etmekteydi. Ancak günümüzde genellikle eski bir ayı postu kullanılmaktadır. 3-7 gün süren törende tatil ilan edilir, bu törenle özdeşleşmiş yemekler yapılır. Törenin ikinci aşamasında özel maskeler ve kıyafetlerle danslar edilir, teatral performanslar sunulur, bu törenle özdeşleşmişş̧arkılar söylenir. Şarkılar genellikle ayı efsanesi konulu, lirik eserlerdir. Teatral dansların konusuna göre hızlı bir ritme de sahip olabilen şarkılar, kadınlar tarafından söylenir.

Orta Asya törenlerinin genel özelliğine uygun olarak Ayı Töreni de müzik eşliğinde gerçekleştirilir. Başta şaman davulu olmak üzere bazı çalgıların erkekler tarafından çalındığı görülse de, bu törende müzik yapmak, genellikle kadınların görevidir. Törenin ana kahramanı olan ayının ruhuna yol göstermek için kam davulu ve brevne isimli çalgıdan faydalanılır. Sadece Ayı Töreni için kullanılan ve kadınlar tarafından çalınan brevne adlı vurmalı çalgının yanı sıra, ziller, pagremuşka olarak adlandırılan çıngırak ve marakaslar, nars-yuh ve sungultap adlı telli çalgılar ve son dönemlerde kullanılmaya başlayan titra çalgıları ile yapılan müzik, Ayı Töreninin en önemli parçalarındandır.

\section{Açıklamalar}

$1 \quad$ “Rus biliminsanı” ifadesi ile Rus kimliği taşıyanların hepsi kastedilmektedir. Ancak Rus kimliği taşısalar da Taksami gibi bazı biliminsanları, Nivh ya da farklı kökene sahiptir.

2 Az sayıda perdeden oluşan mod ya da diziye dayanan müzik.

3 Bu konuda detaylı bilgi için bk. Elena Glavatskaia, "Religious And Ethnic Identity Among The Khanty : Processes Of Change”; Saarniit, H. (2011). 
"The Khanty of Western Siberia: Elements of Shamanism as a Form of Cultural Identity", N. Neyman. "An Ethnohistorical Dictionary of the Russian and Soviet Empires"

\section{Kaynaklar}

Baykara, Tuncer (2001). Türk Kültür Tarihine Bakışlar. Ankara: AKM Yay.

Brunner, Bernd (2016). A Groundbreaking Exhibition in Frankfurt Investigates Early Human-Bear Interaction. http://thesmartset.com/bearing-witness/ (Yayınlanma Tarihi: 25.01.2016). (Erişim Tarihi: 07.10.2016).

Çavuşoğlu, Yağmur (1986). "Eski Türk Dini”. Tanıtım 7/79: 28-30.

Çoruhlu, Yaşar (2002). Türk Mitolojisinin Ana Hatları. İstanbul: Kabalcı Yay.

Dimitrieva, Tatyana Nikolaeva (2013). “О Возможности Выявления Общих Черт Почитания Медведя У Обских Угров И Народов Дальнего Востока”. Цикличность: динамика культуры $u$ сохранение традиции, (Теория и методология архаики; Вып. 6). РАН (Rusya Bilimler Akademisi). 154-164.

Drury, Nevill (1996). Şamanizm ve Şamanlığın Öğeleri. Çev. E. Şimşek. İstanbul: Okyanus Yay.

Efendiyeva, Çiçek (2003). "Eski Rus “İgor Destanı” Adlı Eserdeki Eski Türk Kökenli Kelimeler Üzerine Bir İnceleme”. bilig, Türk Dünyası Sosyal Bilimler Dergisi 24: 45-64.

Fadeeva, Elena Viktorovna (2013). “Роль женщины в традиционных родовых праздниках и промысловых обрядах у коренных народов Нижнего Амура". Ойкумена - Регионоведческие Исследования 3 (26). УДК 394.2 (571.62): 76-85.

Fedotoviç, Jelobtsov F. (1994). "Saha Yeri ve Saha Türkleri”. Haz. Saadettin Gömeç. Ankara Üniversitesi Dil ve Tarih- Coğrafya Fakültesi Tarih Bölümü Tarih Araştırmalar Dergisi 26 (16): 227-241.

Friedrich and Diamond (1994). Encyclopedia of World Cultures: Russia and EurasiaChina. Volume 6. Boston: G. K. Hall and Company.

Forsyth, James (2006). A History of the Peoples of Siberia: Russia's North Asian Colony 1581-1990. Cambridge University Press.

Gömeç, Saadettin (1998). “Tarihte ve Günümüzde Saha Türkleri”. Ankara Üniversitesi Dil ve Tarih-Coğrafya Fakültesi Tarih Bölümü Tarih Araştırmaları Dergisi 30 (19): 175-203.

Glavatskaia, Elena (2001). "Religious And Ethnic Identity Among The Khanty: Processes Of Change". Senri Ethnological Studies 56: 15-26. 
Groot, Jan Jakob Maria de ve G. Ahmetcan Asena (2011). 2500 Çin Imparatorluk Belgeleriyle Hunlar ve Türkistan. İstanbul: Pan Yay.

Hoppal, Mihaly (2001). “Sibirya Şamanizminde Doğa Tapınımı”. Ankara Üniversitesi Dil ve Tarih-Coğrafya Fakültesi Dergisi 41 (1): 209-225.

İllarionov, Vasiliy Vasilevich (2013). “Сказительская Традиция Народов Якутии: Сравнительно-Типологический Аспект”. İdil 2 (9): 1-7.

İzgi, Özkan (1977). "Hunlar, Göktürkler ve Uygurlarda Geleneksel Festival ve Eğlenceler”. I. Ü. Tarih Dergisi 31: 29-36.

Khanty Bear Festival Kazym Siberia, Part 1: Museums and Reindeerherders Day (2015). Grönklitt: Predator Center.

Khanty Bear Festival Kazym Siberia, Part 2: Bear Festival Kazym Villiage (2015). Grönklit: Predator Center.

Khataliev German - Klavdia Khatyleva (2015). Торут Дорбоон. Тичик. Yakutsk.

Kimball-Davis, Jeannine, Vladimir A. Basilov ve Leonid T. Yablonsky (1995). Nomads of the Eurasian Steppes in the Early Iron Age. Berkeley: Zinate Press.

Liarskaya, Elena V. (2009). "Settlement Nenets On The Yamal Penınsula: Who Are They?". Folklore 41: 33-46.

Mamçeva, Natalya A. (2010). Музыка Медвежьего Праздника Сахалинских Нивхов. Sanatta Yeterlik Tezi. St. Petersburg: Rimsky Korsakov Devlet Konservatuvar1.

Nikolayeva, Valeria (2015). “Медвежий Праздник”. http://national-travel.ru/asia/ trad-asia/medvezhii-prazdnik.html. (Erişim Tarihi: 28.03.2016).

Ögel, Bahaeddin (1982). Büyük Hun İmparatorluğu Tarihi. C. I-II. Ankara: Kültür Bakanlığ Yay.

Ögel, Bahaeddin (1988). Türk Kültürünün Gelişme Çağlart-Dünden Bugüne. İstanbul: Türk Dünyası Araştırmaları Vakfı Yay.

Pataçakov K.M. (1958). Культура $u$ быт хакасов в свете исторических связей $c$ русским народом VIII XIX вв., хакасское книжное издательство. Abakan.

Rasonyi, Lazslo (1993). Tarihte Türklük. Ankara: TKAE Yay.

Saarniit, Helen (2011). "The Khanty of Western Siberia: Elements of Shamanism as a Form of Cultural Identity”. http:/www.culturaldiplomacy.org/academy/content/ pdf/participant-papers/2011-08-loam/The-Khanty-of-Western-Siberia-Elementsof Shamanism-as-a-Form-of-Cultural-Identity-Helen-Saarniit.pdf (Erişim Tarihi: 02.11.2016).

Skrıbıkina, Çayanda Kimovna (2007). “Ладовые Особенности В Музыке Современных Якутских Композиторов”. Вестник Челябинского государственного университета 15. УДК: 7: 165-170.

Taksami, Çuner Mihayloviç (1992). "Медвежий праздник в традиционном мировоззрении на-родов Севера”. Ранние формы религии народов 
Сибири: Материалы III Советско-Французского Симпозиума (III. Sovyet Fransız Sempozyumu). СПб. МАЭ. 156-166.

UNESCO Red Book on Endangered Languages: Northeast Asia, http://www.helsinki. $\mathrm{fi} /$-tasalmin/nasia_report.html (Erişim Tarihi: 12.12.2016).

Vertkov, Konstantin Aleksandroviç, G. Blagolatov ve E. Yazovitskaya (1963). Музыкальные инструменты Народов СССР. Moskova.

Vorobeva Victoria, Zoya Fedorinova ve Ekaterina Kolesnik (2015). “Three Crucial

Crises in the Development of the Khanty and Mansi Unique Culture". XV International Conference "Linguistic and Cultural Studies: Traditions and Innovations". LKTI. 9-11 Kasım. Russia: Tomsk. 108-113.

Yiğit, Ali (2006). "Rusya Federasyonu’nda Türk Topluluklarının Yaşadığı Bölgelerdeki

Nüfus Hareketleri ve Değişen Etnik Yapı”. Ülkümüz 3 (6): 69-88.

Духи агропарка. http://ampravda.ru/2013/05/16/038495.html (Erişim Tarihi:

Kasım 2016) (Resim 2)

Шаманы, Колдуны $u$ их Духи, http://e-davidich007.livejournal.com/27262.html

(Yayınlanma Tarihi: Mayıs 2015). (Erişim Tarihi: Aralık 2016). (Resim 1)

http://gotoural.com/tours/115, «Манси. Культ медведя. Медвежий праздник»

в Историко-этнографическом парке «Земля предков» (Erişim Tarihi:

07.10.2016) (Resim 35-39, Resim 46)

http://national-travel.ru/asia/trad-asia/medvezhii-prazdnik.html (Erişim Tarihi:

28.03.2016). (Resim 29, Resim 48-50)

http://nazaccent.ru/content/11392-prezident-spaseniya-yugry-vyskazalsya-pro-

tiv-provedeniya. html, Президент “Спасения Югры” высказался против

проведения Медвежьих игрищ в Москве. (Yayın Tarihi: 20.04.2014). (Erişim

Tarihi: 02.09.2016). (Resim 30)

http:// sakhalin-museums.ru/excursion/2272/ (Erişim Tarih Dilimi: 10.09.2016-

16.12.2016). (Resim 22)

http://sch-6.edusite.ru (Erişim Tarihi: 19.03.2016). (Resim 57, Resim 65)

http://ugra.aif.ru/society/1474061, В селе Казым прошел праздник обских угров

«Медвежьи игрища» (Yayın Tarihi: 18.03.2015). (Erişim Tarihi: 10.10.2016).

(Resim 28, Resim 27, Resim 32, Resim 34)

https://yakutskhistory.net/культура/медвежий-праздник (Erişim Tarihi: 14.10.2016). (Resim 26)

\section{Kaynak Kişiler}

KK1: Ludmila Stepanovna Efimova, Halk Edebiyatı Uzmanı (Doçent Doktor)

(Görüşme Tarihi: 25.07.2017-04.08.2017)

KK2: Valentina Yu Süzükei. Müzikolog, Tuva-Kızıl, (Görüşme Tarihi: 09-10.08.2017)

KK3: Zoya Kırgısovna Kırgıs, Müzikolog, Tuva-Kızıl, (Görüşme Tarihi: 13.08.2017) 


\title{
Bear Festival in Yakut Turks, Khanty-Mansi and Nenets and Musical Instruments Used in the Festival ${ }^{*}$ \\ Feyzan Göher Vural ${ }^{* *}$
}

\begin{abstract}
Ceremonies and festivals have an important place in the cultural wealth of a community. The practices in these ceremonies contain important clues about the history of the society and the values it has. The "bear ceremony" has its own distinctive features in terms of its rituals and musical practices. This ceremony is based on hundreds of years of history among the Sakha (Yakut) Turks and the Khanty-Mansi, the Nivhs and the Nenets, who are thought to be from the indigenous peoples of Siberia. This ceremony, which is linked to the belief in sacred nature beings among the Central Asian Turks and close neighbor / relative communities, includes comprehensive rituals. The hunting, killing and eating of the bear are made with some traditions. Music and music instruments have a special position in these traditions.

This descriptive research is based on the detection of findings which are obtained from Russian, Turkish and English sources. The findings have been reviewed in terms of historical and musicological perspectives. It has been emphasized that the origin and rituals of the Bear Ceremony and music instruments such as brevne which identified with this ceremony in this study.
\end{abstract}

\section{Key Words}

Bear Ceremony, Sakha (Yakut) Turcs, Khanty-Mansi, Nenets, musicology.

\footnotetext{
Date of Arrival: 29 December 2016 - Date of Acceptance: 01 March 2017

You can refer to this article as follows:

Göher Vural, Feyzan (2019). "Saha Türkleri, Hantı-Mansi, Nenets Topluluklarında Ayı Töreni ve Törende Kullanılan Çalgılar”. bilig - Türk Dünyası Sosyal Bilimler Dergisi 88: 83-112.

". Professor, Niğde Ömer Halisdemir University, Turkish Music Conservatory,

Department of Musicology - Niğde/Turkey

ORCID ID: https://orcid.org/0000-0001-5313-0763

feyzan_goher@yahoo.com
} 


\title{
Фейзан Гёхер Вурал
}

\begin{abstract}
Аннотация
Праздники и фестивали занимают важное место в культурном богатстве общества. Обряды, совершаемые во время таких праздников, дают представлениеобисторическихценностях, присущихданномуобществу. «Медвежий праздник», устраиваемый народом Саха (Якутии), а также хантами, манси, нивхами и ненцами, которые являются коренными народами Сибири, и существующий уже сотни лет, с точки зрения ритуалов и музыкального сопровождения имеет различные уникальные особенности. Это празднество, связанное с верой в сверхъестественную силу природных существ среди тюркоязычных и соседних/ родственных народов Средней Азии, оно включает в себя комплекс обрядов. Совершаются ритуалы охоты, свежевания и поедания мяса медведя. Обряды сопровождаются песнями и игрой на музыкальных инструментах.

Описательный характер данной работы опирается на интерпретацию исторических и музыковедческих выводов, полученных в результате исследования различных источников на русском, турецком и английском языках. В работе сделан акцент на зарождение медвежьего праздника, ритуалы, используемые музыкальные инструменты, а также рассмотрено предназначение и особенности отождествляемого с данным празднеством такого музыкального инструмента, как бревно.
\end{abstract}

\section{Ключевые слова}

Медвежий праздник, народ Саха (Якуты), Ханты и Манси, Ненцы, музыковедение.

\footnotetext{
Поступило в редакцию: 29 декабрь 2016 г. - Принято в номер: 1 март 2017 г.

Ссылка на статью:

Göher Vural, Feyzan (2019). "Saha Türkleri, Hantı-Mansi, Nenets Topluluklarında Ayı Töreni ve Törende Kullanılan Çalgılar”. bilig - Türk Dünyası Sosyal Bilimler Dergisi 88: 83-112.

** Профессор, Университет Омера Халисдемира в Нииде, консерватория турецкой музыки, отделение музыковедения, Нииде/Турция ORCID ID: https://orcid.org/0000-0001-5313-0763 feyzan_goher@yahoo.com
} 